SpringerLink Header: Susceptibility Factors in Environmental Health (B Ritz, Section Editor)

\title{
Susceptibility Factors Relevant for the Association Between Long-Term Air Pollution Exposure and Incident Asthma
}

Emilie Burte $^{\mathrm{a}, \mathrm{b}}$, Rachel Nadif, PhD, ${ }^{\mathrm{a}, \mathrm{b}}$, Bénédicte Jacquemin, MD, PhD, ${ }^{\mathrm{a}, \mathrm{b}, \mathrm{c}, \mathrm{d}, \mathrm{e}}$

a. INSERM, U1168, VIMA: Aging and chronic diseases. Epidemiological and Public health approaches, F-94807, Villejuif, France

b. Univ Versailles St-Quentin-en-Yvelines, UMR-S 1168, F-78180, Montigny le Bretonneux, France

c. CREAL-Centre for Research in Environmental Epidemiology Parc de Recerca Biomèdica de Barcelona, Barcelona, Spain.

d. Universitat Pompeu Fabra (UPF), Barcelona, Spain

e. CIBER Epidemiología y Salud Pública (CIBERESP), Barcelona, Spain

\section{Corresponding author:}

Bénédicte Jacquemin

INSERM - UMR-S 1168 - VIMA

Currently at

CREAL-Centre for Research in Environmental Epidemiology

Parc de Recerca Biomèdica de Barcelona

Doctor Aiguader, 88

08003 Barcelona

Spain

Tel. + 34932147359

Fax. + 34932147302

benedicte.jacquemin@inserm.fr

Keywords Air pollution; incident Asthma; susceptibility factors; long-term exposure;

\begin{abstract}
In this review, we identified 15 studies in children and 10 studies in adults that assessed the association between long-term exposure to air pollution and incident asthma and that conducted stratified analyses to explore potential susceptibility factors. Overall, adult never/former smokers seem to be at higher risk of incident asthma due to air pollution. Children without atopy and children from low socio-economic status families also seem to be at higher risk of incident asthma due to air pollution. While interaction between air pollution and genes involved in the response to oxidative stress pathways have been explored, results are somewhat inconsistent and in need of replication. To evaluate interactions, large sample sizes are necessary and much more research, including data pooling
\end{abstract}


from existing studies, is needed to further explore susceptible factors for asthma incidence due to long-term air pollution exposure.

\section{Introduction}

Ambient air pollution has been associated with several health outcomes such as cardiovascular and respiratory diseases [1], lung cancer [2] or low birth weight [3]. Some specific population groups seem to be more sensitive to air pollution effect such as children, elderly people, overweight or obese individuals [4], subjects with chronic respiratory disease such as asthma [5] or chronic obstructive pulmonary disease [6]. Sex differences have also been found [7]. Regarding air pollution, there is no consensus on specific susceptibility factors that would be common across all health outcomes. The association between air pollution and asthma has been widely studied, some studies evaluated acute exposure to air pollution and its relation with asthma exacerbation or hospitalization [8], others have evaluated long-term air pollution and its relation with prevalence and incidence of asthma [9]. To our knowledge there is no (systematic) review that has evaluated potential susceptibility factors in relation to the effects of air pollution on incident asthma. Thus, the aim of this review is to fill this gap by summarizing results from studies that reported on air pollution and incident asthma while stratifying on possible susceptibility factors.

\section{$\underline{\text { Methods }}$}

This review focuses on studies that assessed the effect of long-term air pollution on asthma incidence and reported stratified analysis on possible susceptibility factors. Through a PubMed research, we selected articles in peer-reviewed journals. The search terms included "air pollution" and "asthma or wheeze" - in title or abstract- and "inciden*" or "onset". The search resulted in 272 papers, for which we screened the title, the abstract and the full article when necessary to identify studies according to the criteria that will be described here. We also compared the list with recent reviews based on the effect of air pollution on asthma [8-10], confirming that our search did not miss any eligible paper. We included only articles in English, in adults or children (not animals) that studied long-term pollution effects on incidence asthma, and that stratified on possible susceptibility factors (Flow-chart of the articles selection is available in Figure 1).

\section{Pollution exposure}

Pollutants studied in the articles were: nitrogen oxides (NOx), nitrogen dioxide $\left(\mathrm{NO}_{2}\right)$, particulate matter up to $10 \mu \mathrm{m}\left(\mathrm{PM}_{10}\right)$, particulate matter up to $2.5 \mu \mathrm{m}\left(\mathrm{PM}_{2.5}\right)$, ozone $\left(\mathrm{O}_{3}\right)$, sulfur dioxide $\left(\mathrm{SO}_{2}\right)$ and soot. Most of the papers included in this review used modeled (land-use regression (LUR) or dispersion models) exposure at individuals' residential addresses [11-26], one study used modeled individual exposures at both home and school addresses [27]. Three articles used proximity to 
traffic/major roads as a proxy of air pollution exposure, one relied on residential address [28], one on school and home addresses [29] and one on school address only [30]. Two studies used community exposure to air pollution as proxies of individual exposure [31,32] and three studies used zip code level exposures corresponding to home and work/school [33-35].

\section{Asthma incidence}

In adults, incident asthma was the variable of interest whereas in children incident asthma or incident wheeze were considered. Incident asthma or wheeze was assessed mostly using questionnaires and questions used across studies vary from report of asthma symptoms to report of diagnosed asthma (parental report for children). Five studies used a physician diagnosis of incident asthma (personal visit to the physician) $[17,18,20,29,35]$. One study used asthma symptom score as a proxy to identify asthma incidence [23].

\section{Susceptibility factors}

The susceptibility factors of a-priori interest were:

- Age: effect of air pollution exposure could differ according to each stage of life [4] (in particular prenatal period [36], early childhood, and in the elderly [37]). Actually, regarding age, two concepts appear. From the one side the age of exposure and from the other side the age at diagnosis. Regarding the first, it is possible that there are different windows of susceptibility. Regarding the latest, it is well known that childhood asthma is different from adulthood asthma and within adulthood asthma, teenage or elderly asthma can be also different phenotypes, and thus air pollution could have a different effect on these different phenotypes. Most of the studies stratified their analyses on age using age at inclusion or follow-up (possibly trying to integrate both concepts). However, some birth cohorts have air pollution exposure during pregnancy or early in life, and therefore stratified by age of exposure

- Sex/gender: exposure to air pollution could be different according to gender (for example women spending more time at home), or the effect of air pollution could be biologically different according to sex. Throughout the manuscript we will use the term "sex" as it is very difficult to disentangle what is related to sex -biological differences- and what is related to gender - life habits differences- regarding air pollution effects [38].

- Tobacco -secondhand smoke for children-: air pollution effects could be masked among smokers (or passive smokers) as smoking and air pollution share several mechanisms [24], furthermore recently it has been suggested that there could be an interaction between smoking and air pollution [39].

- Atopy: atopic and non-atopic asthma are possibly two different diseases with different mechanisms, and air pollution may have a different effect according to atopy status [40]. 
- Body mass index (BMI): subjects with obesity have been found to be more susceptible to air pollution in terms of lung function (and as lung function is an asthma related phenotype, it seems plausible that susceptibility factors related to lung function may also be interesting to study regarding asthma incidence) and asthma [41-43].

- Genetic variants [4]: mainly the ones associated with oxidative stress or inflammation are the ones investigated so far.

During the review we also identified a posteriori socio-economic status (SES, individual SES for adults, family SES for children) or- family environment (such as parental stress or exposure to violence), race, wheeze or bronchial hyperresponsiveness at baseline and parental history, as being others potentials susceptibility factors that we will expose in the manuscript.

\section{$\underline{\text { Results and discussion }}$}

Twenty-five articles fulfilled the inclusion criteria (17 from the PubMed research and 8 from the hand research) (Figure 1) and are presented separately for adults and children. Study characteristics and main results for each study are summarized in Table 1 for children and in Table 2 for adults.

\section{Sex:}

Seven studies stratified the effects of air pollution on asthma by sex [13,14,17-19,30,35] in children. In Canadian children at high risk for asthma [17], the association between exposure -measured at year of birth- and incident asthma at 7 years old was reported as higher among boys, but no further details were given. In a pregnancy cohort in US [19], the association between in- utero exposure to $\mathrm{PM}_{2.5}$ and asthma onset at age 6 showed a sensitive exposure window between 12-26 weeks of gestation for boys but not for girls, and the authors reported a significant interaction term for sex (p-interaction=0.01, $\mathrm{OR}\left(\mathrm{PM}_{2.5}\right.$ *boys): $\left.1.33(1.05-1.69)\right)$. In the five other studies, associations were similar in boys and girls: in children aged 6-9 years from the Chiba prefecture in Japan [30], the association between air pollution, measured as school proximity to traffic and asthma incidence was similar in boys and girls (OR(95\%CI): 3.75(1.00-14.06) for boys and 4.06(0.91-18.10) for girls). The same result was found among more than 4000 children aged 8-21 years from US and Puerto Rico [18], for $\mathrm{NO}_{2}$ and PM $\left(\mathrm{PM}_{2.5}\right.$ and $\left.\mathrm{PM}_{10}\right)$, considering air pollution exposures during the first year of life or first 3 years of life (First year of life: $\mathrm{NO}_{2}$ : $\mathrm{OR}(95 \% \mathrm{CI})$ : $1.26(1.05-1.52)$ in boys, 1.11(0.96-1.29) in girls; $\mathrm{PM}_{10}$ : $1.10(0.89-1.36)$ in boys, $1.15(0.97-1.37)$ in girls, the p-interaction was not significant. First 3 years of life: $\mathrm{PM}_{10}$ : 1.08(0.86-1.35) in boys, 1.19(1.00-1.41) in girls, p-interaction NS). In a Swedish birth cohort [13], association between traffic NOx and persistent wheezing was also similar whatever the $\operatorname{sex}(\mathrm{OR}(95 \% \mathrm{CI})=1.94(1.07-3.50)$ in girls, OR: 1.55(0.92-2.63) in boys, p-interaction=0.43). In another birth cohort conducted in Oslo, $\mathrm{NO}_{2}$ was not associated with asthma incidence among girls (RR (95\%CI): 1.05 (0.74-1.49)), while the effect estimate was negative among boys (RR: 0.73(0.56- 
0.95), p-interaction=0.10). Finally, in Canadian children aged between 36 and 59 months [35], associations were similar in boys and girls for both $\mathrm{NO}$ and $\mathrm{NO}_{2}\left(\mathrm{OR}(95 \% \mathrm{CI})\right.$ for $\mathrm{NO}_{2}$ : 1.17(1.091.26) for girls and 1.09(1.03-1.16) for boys, OR for NO: 1.13(1.06-1.20) for girls and 1.05(1.00-1.10) for boys) .

In adults, six studies stratified by sex when they assessed the associations between air pollution and asthma [22-24,28,33,34]. In American non-smokers [34], for an IQR increase in 20-years average of $\mathrm{O}_{3}-8 \mathrm{~h}$ concentration, the association was positive in men, while there was no association in women ( $\mathrm{RR}(95 \% \mathrm{CI})$ : $2.09(1.03-4.16)$ in men, $0.86(0.58-1.26)$ in women); in the same study population, another paper [33] reached a similar conclusion when considering one-year O3-8h average as exposure. In an European study conducted in 7 countries [23], the association between $\mathrm{NO}_{2}$ concentration and incident asthma was similar but slightly stronger among men $(\mathrm{OR}(95 \% \mathrm{CI})$ : 1.32(1.12-1.56), than among women (1.14(0.97-1.34; , p-interaction=0.13). Among Swiss neversmokers [24], the OR per $1 \mu \mathrm{g} \cdot \mathrm{m}^{-3}$ increase in traffic related $\mathrm{PM}_{10}\left(\mathrm{TPM}_{10}\right)$ was also slightly higher in men -but no precise OR were available as results were presented only in a figure-. Other studies found no significant difference between men and women in the association between air pollution and asthma [22,26,28]: no difference according to sex was found in an European study conducted in 7 countries (OR for $\mathrm{NO}_{2}: 1.31(0.76-2.27)$ in men and 1.53(0.99-2.38) in women (p-interact=0.69), [22]) nor in a Swedish cohort (OR for $\mathrm{NO}_{2}: 1.32(0.64-2.74)$ in men, $1.67(0.98-2.74)$ in women (p-interact=0.63), [28]). Similarly, in a European study regrouping 6 cohorts, no difference was found according to the sex and no association between air pollution and incident asthma was found (OR for $\mathrm{NO}_{2}$ : $1.06(0.92-$ 1.24) in men, 1.07(0.97-1.19) in women, p-interact=0.66, $\mathrm{PM}_{10}: 1.00(0.63-1.59)$ in men, $1.07(0.91$ $1.26)$ in women, $\mathrm{p}$-interact $=0.80[26])$.

Both in adults and children, sex was the most studied susceptibility factor. Among children, similar effect of air pollution on incident asthma was similar in boys and girls. Among adults, results are discordant with some studies showing a higher effect of air pollution exposure on incident asthma in men whereas others reported no difference according to sex. This is opposite to what Clougherty [38] pointed out in her review where she found a higher effect of air pollution among women. Overall, in both adult and children, evidence mostly support no effect modification between air pollution measures and sex on incident asthma.

Age:

In children, three studies stratified their analysis on age, [11,16,27]. In children from Lanceister aged 1-5 years at baseline [11], no evidence for a modifier effect of age (1-2.9 years vs. 3-4.9 years) was found. In a Netherland birth cohort [16], a slightly higher association of air pollution and onset asthma at 6-8 years $v s$. younger (age at follow-up, no exact OR available only OR showed in a figure) was found. Among children followed-up at 1, 2, 4, and 12 years of age in a Swedish birth cohort [27], association between air pollution during first year of life and asthma risk increased with age 
$\left(\mathrm{OR}(95 \% \mathrm{CI})=1.48(0.85-2.57)\right.$ for $\mathrm{NOx}$ and 1.59(0.83-3.05) for $\mathrm{PM}_{10}$ at 4 years of age at follow-up and 1.87(1.01-3.44) for NOx and 2.39(1.18-4.86) for $\mathrm{PM}_{10}$ at 12 years at follow-up).

In adults, we found only two studies stratifying the analysis of the association between air pollution and incident asthma according to age at baseline [24,26]. Among Swiss non-smokers [24], the association between traffic related $\mathrm{PM}_{10}$ and incident asthma was slightly higher among participants aged of more than 40 years at baseline $(\mathrm{OR} \approx 1.65$ significant in $>40$ years, $\mathrm{OR} \approx 1.3 \mathrm{NS}$ in $<=40$ years, no exact OR available, p-interact $>0.1$ ). In a meta-analysis of 6 European studies [26], no difference was found in the association between $\mathrm{NO}_{2}$ and incident asthma in participants with more or less than 50 years old at baseline.

In children as in adults, only few studies stratified on age -whatever age at baseline or age at followup- and no particular patterns were found, except perhaps stronger estimated effects among children between 6 to 12 years at diagnosis. As epidemiological studies are either conducted among adults or among children, and often focus on a specific age range, few studies stratify the results according to age. However it is of special interest that one study reported higher incidence of asthma in children (even if only boys) who were more exposed in utero during 12-26 weeks of gestation pointing out to a possible prenatal susceptibility window [19]. This result is concordant with a study that found that prenatal exposure to air pollution was associated with long-term lung function deficits at preschool age [44].

\section{Smoking:}

In children, we found no study that stratified on passive smoking or maternal smoking. A study in children from Lanceister, however stated that the "effect of $\mathrm{PM}_{10}$ on health outcomes did not depend on whether children were exposed to secondhand tobacco smoke (p-interaction>0.1)" [11]. Generally, this factor was taken into account in the adjusted models.

In adults, five studies stratified their analysis on smoking status, but classification of smoking was not homogenous across studies. An American study of women and a European study grouped never and ex-smokers together. In both studies, they found a higher association between $\mathrm{NO}_{2}$ and asthma or wheeze incidence among ex/never smokers (American study: OR $(95 \% \mathrm{CI})=1.14(1.04-1.24)$ in never/ex-smoker and 0.89(0.74-1.06) in current smoker, p-interaction=0.01 [25], European study: $1.30(1.11-1.52)$ in never/ex-smokers and 1.07(0.92-1.26) in current smokers, p-interaction=0.005 [23]). The interactions were significant in both studies, but the first one only stratified on smoking status for incident wheeze, due to a lack of power for incident asthma, and this population was restricted to women. Another study conducted in 7 European countries [26], considered ex-smokers and current smokers together, and associations were slightly stronger for $\mathrm{NO}_{2}$ among ever smokers $(\mathrm{OR}(95 \% \mathrm{CI})$ : $1.13(0.99-1.29)$ than never smokers $(\mathrm{OR}=1.01(0.88-1.16 ; \mathrm{p}$-interact $=0.35)$ and no difference was found for $\mathrm{PM}_{10}$ in ever smokers $(1.17(0.79-1.74)$ versus never smokers $(\mathrm{OR}=1.10(0.87$ - 
1.39). Among American non-smokers [34], the association between ozone and incident asthma was similar among ex-smokers and never smokers, but stratification was only done for men. In another study, for non-smokers only [24], there was an association between traffic related $\mathrm{PM}_{10}$ and incident asthma among never smokers $(\mathrm{HR}(95 \% \mathrm{CI})=1.30(1.05-1.61)$ but no association among ex-smokers $(\mathrm{HR}=0.99(0.64-1.53))$. They also reported no association between air pollution and asthma in smokers. Overall, the association between air pollution and incident asthma according to smoking status was studied only in adults, and while results were not always consistent, the effects of air pollutant on incident asthma seemed to be stronger among never/ex-smokers. This susceptibility might be explained by the fact that any air pollution effect may be masked among smokers, who may already have a higher risk of asthma [45].

\section{Atopic status:}

Five studies stratified their analyses according to atopy status in children. Atopy status was defined according to level of specific Immunoglobulin E (IgE, >35kU/L) [13,16,27], positive skin-prick test (SPT) [29], or level of total IgE (Total $\operatorname{IgE} \geq 200$ ) [18]. Two birth cohorts [13,16,27] reported a stronger association between air pollution and incident asthma in non-atopic children: a Swedish birth-cohort [13] reported an association between NOx exposure and incident asthma in non-atopic children and no association in atopic children at age 4 (OR(95\% CI): 1.46(1.00-2.13) in non-atopic, 1.11(0.55-2.22) in atopic, p-interaction NS). Another study conducted in the same birth cohort [27] reached similar results for exposure to $\mathrm{PM}_{10}$ and NOx and incident asthma at age 8 (OR(95\%CI) for NOx: 2.6(0.9-8.1) in non-atopic, 0.8(0.2-2.4 in atopic). In a Dutch birth-cohort [16], the association between $\mathrm{NO}_{2}, \mathrm{PM}_{2.5}$ and soot and incident asthma were higher among non-atopic children at age 8 , but in this study it was not possible to adjust for any type of confounding due to small sample size (OR(95\% CI) for $\mathrm{NO}_{2}$ : $1.85(0.92-3.73)$ in non-atopic, $0.95(0.64-1.40)$ in atopic). Contrary to all of these results, a French case-control study examined traffic density -expressed in tertiles- before age 3 [29], and associations between traffic density and incident asthma were stronger among atopic children, but with wide confidence intervals and results were probably mainly driven by the way they categorized exposure (tertile 1 as reference. OR(95\%CI): tertile2: 0.61(0.1-3.6) and tertile3: 11.03(1.3-100.9) and in nonatopic tertile2: $1.23(0.29-5.31)$ and tertile3: $1.47(0.32-6.97)$, p-interact=0.20). Finally, in a study in children from US and Puerto Rico [18] there was no differences in estimated effects according to low or high total-IgE level.

In adults, five studies stratified the analyses according to allergic sensitization. Atopy status was defined by a positive SPT [20,24], high levels of specific IgE $[22,23]$ or using the report of hay fever as proxy of allergic sensitization [28]. No difference according to atopic status was found in a European study whatever the way to define asthma incident cases (OR for $\mathrm{NO}_{2}$ : (95\% CI): $1.20(1.02-$ 1.41) in non-atopic, 1.37(1.14-1.65) in atopic, p-interaction=0.63) using asthma symptoms report [23], and 1.31(0.84-2.04) in atopic, $1.57(0.92-2.67)$ in non-atopic, p-interaction=0.77 using symptom score 
of asthma [22]). On the one side, a study in Swiss non-smokers [24] reported an association between $\mathrm{TPM}_{10}$ concentration and asthma incidence among atopic whereas no association was observed among non-atopic participants $(\mathrm{OR} \approx 1.35$ in atopic, $\mathrm{CI}$ higher than $1, \mathrm{OR} \approx 1.2, \mathrm{CI}$ including 1 in non-atopic. OR available in a figure). In a Swedish case control study [20], association reached significance in atopic only (OR for $\mathrm{NO}_{2}$ (95\%CI: 1.2(1.0-1.3) in those with $\geq 1$ SPT, 1.0(0.9-1.1) in those with no SPT), however no significant associations was found for the whole population. On the other side, in a prospective Swedish cohort [28], the association between $\mathrm{NO}_{2}$ and asthma incidence was higher in participants without hay fever (OR(95\%CI): 1.15(0.59-2.24) in those with hay fever, 1.79(1.04-3.05) in those without, $\mathrm{p}$-interaction $=0.30$ ).

Stratification on atopy status was one of the most commonly assessed susceptibility factors, particularly in children. Estimated effects of air pollution on incident asthma seem to be stronger in non-atopic children; possibly because air pollution effects may be masked among atopic participants, a sensitive population who already is at higher risk of asthma. In adults, results were too discordant to come to a conclusion. Allergic and non-allergic asthma could be two distinct diseases, and it may be hypothesized that biological response to air pollution differs according to allergic sensitization. Furthermore, studying the effect or air pollution with and without atopy may help to better understand the mechanism that air pollution exhibits on asthma.

\section{Genetic factors:}

Only two papers -conducted both in the same study- investigated interactions between genetic variants and air pollution on asthma incidence during childhood and adolescence [31,32]. Among children from 12 Southern Californian communities, non-Hispanic whites children carrying at least one "short" allele ( $<23$ repeats) in the HMOX-1 gene and residing in a low ozone communities had a twofold lower risk of new-onset asthma than those residing in high ozone communities ( $\mathrm{HR}(95 \% \mathrm{CI})$ : 0.44(0.23-0.83) for low-ozone communities, 0.88(0.33-2.34) for high ozone communities, pinteraction $=0.003$ [31]). Associations did not vary according to children's participation in sports or time spent outside [31] . No interaction was found with $\mathrm{PM}_{10}$ [31]. Among children from the same cohort, those homozygous for Ile105 in the GSTP1 gene and playing more than 2 team sports risk of asthma was increased, and the risk was highest in those living in high ozone communities (HR(95\%CI): 1.06(0.3-4.0) in low-ozone community, 6.15(2.2-7.4) in high-ozone communities, pinteraction=0.10, [32]).

In adults, only one study investigated interactions between genetic variants and $\mathrm{NO}_{2}$ concentration on asthma incidence [21]: in an European prospective cohort, subjects homozygous for the NQOI rs291766 C allele were at greater risk for developing asthma due to air pollution compared with those with CG/GG genotypes (OR(95\%CI): 2.02(1.16-3.73) in those homozygous for the NQO1 rs291766 $\mathrm{C}$ allele, as compared with those with CG/GG genotypes: (OR(95\% CI): 1.26(0.83-1.99), pinteraction $=0.04)$. 
Polymorphisms in few genes involved in xenobiotic metabolism or in the NRF2-mediated oxidative stress response modified associations between ozone and asthma incidence in children and adolescents, and between $\mathrm{NO}_{2}$ and adult onset-asthma. No association was observed with PM, suggesting different chemical mechanism of action between pollutants. Overall, results confirm the complex interplay between pollutant, ethnicity, exercise and antioxidant defenses on the development of asthma.

\section{Familial environment and SES:}

Among Californian children age 5-9 years at baseline [15], those exposed to a higher level of parental stress were more susceptible in the association between NOx and incident asthma (HR(95\%CI): 1.51(1.16-1.96) in high parental stress, 1.05(0.74-1.49) in low parental stress, p-interaction=0.05) and this association was greater in boys. A stronger association was also found among children with low SES (1.20(0.93-1.55) in high SES, 1.55(1.09-2.19) in low SES, p-interaction=0.25). In a US birth cohort [12] susceptibility due to exposure to violence was reported: associations between $\mathrm{NO}_{2}$ concentration and incident asthma were stronger among children most exposed to violence (OR(95\%CI): 1.63(1.14-2.33) lower than median exposure, 2.40(1.48-3.88) above median ).

In adults, we found no study that stratified on SES.

Two studies included in our review reported that children with low SES or exposed to a harmful familial environment were at higher risk of asthma due to air pollution, concordant with results related to short-term air pollution [46] or mortality [47] and with the fact that low SES has been traditionally associated with higher air pollution exposure even if recent studies found that this is not always the case [48]. The association between air pollution and SES still needs to be better understood to better explore if SES could be a susceptibility factor in the association between asthma and air pollution.

Some studies assessed others potential susceptibility factors. In Canadian children at high-risk for asthma [17], the association between air pollution and incident asthma seemed stronger among Caucasian participants. In adults, two studies had looked at the association between air pollution and incident asthma according to baseline characteristic associated with asthma: wheeze [28] and BHR [23]. In a Swedish cohort, the association was positive among those with wheezing at baseline, but not in those without wheeze at baseline [28]. In the same way, in a European study, the association was positive and significant among those with BHR at baseline, whereas those without BHR at baseline had a non-significant association [23]. In a Swiss non-smokers population, the association between incident asthma and $\mathrm{PM}_{10}$ level were higher among those with parental history of allergy [24] These results may suggest that participants who are already predisposed to develop asthma or at higher risk of developing asthma may be more susceptible to air pollution.

\section{$\underline{\text { Overall discussion and Conclusion }}$}


In this review, we identified 15 studies in children and 10 studies in adults with stratified analyses on potential susceptibility factors assessing associations between long-term exposure to air pollution and incident asthma. Overall, never/former smokers adults seem to be more susceptible to air pollution in relation to incident asthma. Children without atopy seem to have a higher risk of incident asthma due to air pollution, as well as children with low SES. Some early studies also suggest a role for genes involved in the response to oxidative stress.

We focused on incident asthma, but incident asthma is strongly associated with prevalent asthma, and as they share commons features, we could expect to find similar susceptibility factors for both outcomes. Papers who had specifically studied susceptibility factors of the association between air pollution and prevalence of asthma found discordant results about sex [49,50], parental asthma or allergic symptoms [50,51]. As for incident asthma it seems difficult to draw a firm conclusion on who could be more susceptible to the effects of air pollution. It seems also plausible that susceptibility factors involved in the association between air pollution and lung function have a role in the association between air pollution and asthma onset as lung function is an asthma related phenotype. More previous studies investigated possible susceptibility factors in regard to air pollution and lung function. Downs et al. [52] showed that lung function in adults declined less in area where air pollution improved more, but they did not find any interaction with sex, atopy or smoking status. Another study [53] reported that the association between $\mathrm{NO}_{2}$ concentration and lung function decline was stronger among girls, older children, and stronger but not significant among children of high SES and in those exposed to parental smoking. However the association was not modified by asthma status. Surprisingly, very few studies have assessed the potential role of SES as a susceptibility factor in the association between air pollution and asthma incident, although asthma is known to be socially patterned [54] and SES is very probably associated with air pollution exposure [55]. We found no study with stratified analysis on BMI or dietary factors, despite of the known association between BMI and asthma [43]. Several papers suggested that obesity can play a role in susceptibility to pollutants effects [41,42] in lung function, and in a randomized-trial [56] antioxidant intake was associated with a moderate impact of ozone exposure on lung function in children with moderate to severe asthma. Whereas susceptibility of older adults to the health effects of air pollution is well recognized, and particularly on lung function [57] where frailty was associated with a higher decline of forced vital capacity due to air pollution, we did not find study stratifying on these factors. Others potential susceptibility factors such as low birthweight, second-hand tobacco smoke or ethnicity have also been proposed in a recent review as risk modifiers of the association between air pollution and asthma in general [58], but none of these were taken into account in the articles included in this review. 
One of the limitations of this review is that most of the studies used different methodology to assess air pollution exposure and also different definitions for some susceptibility factors. Some studies assessed the association between several pollutants and incident asthma, and correlations between pollutants were not always taken into account or reported. Some studies did not report the year of exposure assessment and did not clearly define the window of exposure. Whether in children or in adults, half of the studies had considered the problem of participants having moved during the window of exposure to air pollutant. Among those assessing that problem, several had conducted sensitivity analysis, and basically results among non-movers only were either stronger or similar to those among all participants. Another limitation of this review is that several studies did not assess the interaction term related to the susceptibility factor and for those who presented it, only few reported a significant p-value. Among the 25 articles identified, a majority assessed air pollution exposure to $\mathrm{NO}_{2}$ and few assessed PM or other pollutants, making difficult to identify which pollutants could be more important for which susceptibility factor and not allowing to conduct any meta-analysis. Definition of the susceptibility factors differed also according to the study, for example for atopy some studies used IgEs, others SPT and others total IgE or concomitant allergic disease. In children, all studies that found stronger associations among non-atopic participants used specific-IgEs to define atopy while studies using other definitions did not find interactions between atopy and air pollution. Therefore the question arises if the results depend on the way atopy is defined. Differences in exposure or phenotypic characterization, may explain, at least in part, heterogeneity of results across studies.

Regarding genetic factors, it is now well established that asthma is due to a complex interplay of environmental and genetic factors. There have been considerable efforts to characterize the genetic determinants of asthma, however the identified genetic factors explain only a small part of the genetic component of asthma. One of the reasons is that many genetic factors are likely to be involved in the development of asthma through complex mechanisms that involve interactions with environmental factors and with other genes through pathways or networks. Furthermore, the effect of such genetic factors may be missed if genes are considered alone, regardless of the biological functions they shared or the pathways they are involved in [59]. Studies of candidate gene and long-term air pollution for incident asthma are scarce, have been only conducted on genes involved in the response to oxidative/nitrosative stress, and have explored a limited number of genes. Future studies should investigate a greater number of candidates genes selected from a pathway-based approach [60]. The gene selection process may want to integrate information on the biological processes shared by genes, the pathways to which genes belong and the biological knowledge related to the environmental exposure under study.

Overall, no clear susceptibility factors of the relation between outdoor air pollution and incident asthma is currently established. Discordant results could be due to misclassification in exposure such 
as not taking into account time-activity patterns, at it is usually the case in air pollution epidemiological studies. Among the papers included, no study was explicitly designed to assess susceptibility factors for the association between air pollution and incident asthma. Few studies had enough power to stratify or find significant interaction terms. A major challenge in the future would be to have studies specifically designed, or pooling data from existing studies, to address the role of susceptibility factors on the association between air pollution and asthma, and also explore which pollutant is the most relevant for which susceptibility factors. For that purpose, we would need both a detailed characterization of the disease together with a precise modelled individual exposure to air pollution and a better definition of some susceptibility factors such as atopy or smoking.

\section{Acknowledgments}

SESAP: ANSES EST-2012-166.

\section{Compliance with Ethics Guidelines}

\section{Conflict of Interest}

Emilie Burte, Rachel Nadif, and Bénédicte Jacquemin declare that they have no conflict of interest.

\section{Human and Animal Rights and Informed Consent}

This article does not contain any studies with human or animal subjects performed by any of the authors. 


\section{References}

Papers of particular interest, published recently, have been highlighted as:

- Of importance

[1] C. a. Pope, Cardiovascular Mortality and Long-Term Exposure to Particulate Air Pollution: Epidemiological Evidence of General Pathophysiological Pathways of Disease, Circulation. 109 (2003) 71-77. doi:10.1161/01.CIR.0000108927.80044.7F.

[2] G.B. Hamra, F. Laden, A.J. Cohen, O. Raaschou-Nielsen, M. Brauer, D. Loomis, Lung Cancer and Exposure to Nitrogen Dioxide and Traffic: A Systematic Review and Meta-Analysis., Environ. Health Perspect. 123 (2015) 1107-1112. doi:10.1289/ehp.1408882.

[3] M. Pedersen, L. Giorgis-Allemand, C. Bernard, I. Aguilera, A.-M.N. Andersen, F. Ballester, et al., Ambient air pollution and low birthweight: a European cohort study (ESCAPE), Lancet Respir. Med. 1 (2013) 695-704. doi:10.1016/S2213-2600(13)70192-9.

[4] J.D. Sacks, L.W. Stanek, T.J. Luben, D.O. Johns, B.J. Buckley, J.S. Brown, et al., Particulate Matter-Induced Health Effects: Who Is Susceptible?, Environ. Health Perspect. 119 (2010) 446-454. doi:10.1289/ehp.1002255.

[5] J. Sunyer, C. Spix, P. Quénel, a Ponce-de-León, a Pönka, T. Barumandzadeh, et al., Urban air pollution and emergency admissions for asthma in four European cities: the APHEA Project., Thorax. 52 (1997) 760-765. doi:10.1136/thx.52.9.760.

[6] A. Faustini, M. Stafoggia, G. Cappai, F. Forastiere, Short-Term Effects of Air Pollution in a Cohort of Patients With Chronic Obstructive Pulmonary Disease, Epidemiology. 23 (2012) 861-879. doi:10.1097/EDE.0b013e31826767c2.

[7] J.E. Clougherty, L.D. Kubzansky, A framework for examining social stress and susceptibility to air pollution in respiratory health, Environ. Health Perspect. 117 (2009) 1351-1358. doi:10.1289/ehp.0900612.

[8] X. Zheng, H. Ding, L. Jiang, S. Chen, J. Zheng, M. Qiu, et al., Association between Air Pollutants and Asthma Emergency Room Visits and Hospital Admissions in Time Series Studies: A Systematic Review and Meta-Analysis, PLoS One. 10 (2015) e0138146. doi:10.1371/journal.pone.0138146.

[9] B. Jacquemin, T. Schikowski, A. Carsin, A. Hansell, U. Krämer, J. Sunyer, et al., The role of air pollution in adult-onset asthma: A review of the current evidence, Semin. Respir. Crit. Care Med. 33 (2012) 606-619. doi:10.1055/s-0032-1325191.

[10] H.R. Anderson, G. Favarato, R.W. Atkinson, Long-term exposure to air pollution and the incidence of asthma: meta-analysis of cohort studies, Air Qual. Atmos. Heal. 6 (2013) 47-56. doi:10.1007/s11869-011-0144-5.

[11] N. Pierse, L. Rushton, R.S. Harris, C.E. Kuehni, M. Silverman, J. Grigg, Locally generated particulate pollution and respiratory symptoms in young children., Thorax. 61 (2006) 216-220. doi:10.1136/thx.2004.036418.

[12] J.E. Clougherty, J.I. Levy, L.D. Kubzansky, P.B. Ryan, S.F. Suglia, M.J. Canner, et al., Synergistic effects of traffic-related air pollution and exposure to violence on urban asthma etiology, Environ. Health Perspect. 115 (2007) 1140-1146. doi:10.1289/ehp.9863.

[13] E. Nordling, N. Berglind, E. Melén, G. Emenius, J. Hallberg, F. Nyberg, et al., Traffic-related air pollution and childhood respiratory symptoms, function and allergies., Epidemiology. 19 (2008) 401-408. doi:10.1097/EDE.0b013e31816a1ce3.

[14] B. Oftedal, W. Nystad, B. Brunekreef, P. Nafstad, Long-term traffic-related exposures and asthma onset in schoolchildren in Oslo, Norway, Environ. Health Perspect. 117 (2009) 839844. doi:10.1289/ehp.11491.

[15] K. Shankardass, R. McConnell, M. Jerrett, J. Milam, J. Richardson, K. Berhane, Parental stress increases the effect of traffic-related air pollution on childhood asthma incidence., Proc. Natl. Acad. Sci. U. S. A. 106 (2009) 12406-12411. doi:10.1073/pnas.0812910106.

[16] U. Gehring, A.H. Wijga, M. Brauer, P. Fischer, J.C. De Jongste, M. Kerkhof, et al., Trafficrelated air pollution and the development of asthma and allergies during the first 8 years of life, Am. J. Respir. Crit. Care Med. 181 (2010) 596-603. doi:10.1164/rccm.200906-0858OC.

[17] C. Carlsten, A. Dybuncio, A. Becker, M. Chan-Yeung, M. Brauer, Traffic-related air pollution 
and incident asthma in a high-risk birth cohort, Occup. Environ. Med. 68 (2011) 291-295. doi:10.1136/oem.2010.055152.

[18] K.K. Nishimura, J.M. Galanter, L. a. Roth, S.S. Oh, N. Thakur, E. a. Nguyen, et al., Early-Life air pollution and asthma risk in minority children the GALA II and SAGE II studies, Am. J. Respir. Crit. Care Med. 188 (2013) 309-318. doi:10.1164/rccm.201302-0264OC.

[19] - H.-H.L. Hsu, Y.-H.M. Chiu, B.A. Coull, et al., Prenatal Particulate Air Pollution and Asthma Onset in Urban Children: Identifying Sensitive Windows and Sex Differences, Am. J. Respir. Crit. Care Med. 1 (2015) 150715082344002. doi:10.1164/rccm.201504-0658OC.

This paper provides a nice and complete study on the effect of air pollution on incident asthma in children, with data-driven approach to select window of exposure. This paper reported a stronger susceptibility in boys for mid-gestation exposure.

[20] L. Modig, B. Järvholm, E. Rönnmark, L. Nyström, B. Lundbäck, C. Andersson, et al., Vehicle exhaust exposure in an incident case-control study of adult asthma., Eur. Respir. J. Off. J. Eur. Soc. Clin. Respir. Physiol. 28 (2006) 75-81. doi:10.1183/09031936.06.00071505.

[21] F. Castro-Giner, N. Künzli, B. Jacquemin, B. Forsberg, R. De Cid, J. Sunyer, et al., Trafficrelated air pollution, oxidative stress genes, and asthma (ECHRS), Environ. Health Perspect. 117 (2009) 1919-1924. doi:10.1289/ehp.0900589.

[22] B. Jacquemin, J. Sunyer, B. Forsberg, I. Aguilera, D. Briggs, R. García-Esteban, et al., Home outdoor NO2 and new onset of self-reported asthma in adults., Epidemiology. 20 (2009) 119126. doi:10.1097/EDE.0b013e3181886e76.

[23] B. Jacquemin, J. Sunyer, B. Forsberge, I. Aguilera, L. Bouso, D. Briggs, et al., Association between modelled traffic-related air pollution and asthma score in the ECRHS, Eur. Respir. J. 34 (2009) 834-842. doi:10.1183/09031936.00138208.

[24] N. Künzli, P.-O. Bridevaux, L.-J.S. Liu, R. Garcia-Esteban, C. Schindler, M.W. Gerbase, et al., Traffic-related air pollution correlates with adult-onset asthma among never-smokers., Thorax. 64 (2009) 664-670. doi:10.1136/thx.2008.110031.

[25] M.T. Young, D.P. Sandler, L. a DeRoo, S. Vedal, J.D. Kaufman, S.J. London, Ambient Air Pollution Exposure and Incident Adult Asthma in a Nationwide Cohort of US Women., Am. J. Respir. Crit. Care Med. 190 (2014) 914-921. doi:10.1164/rccm.201403-0525OC.

[26] • B. Jacquemin, V. Siroux, M. Sanchez, et al., Ambient Air Pollution and Adult Asthma Incidence in Six European Cohorts (ESCAPE), Environ. Health Perspect. 123 (2015) 613-621. doi:10.1289/ehp.1408206.

This meta-analysis provides a complete study of the association between incident asthma and air-pollution in 6 European Cohort, with several stratified analysis on different susceptibility factors.

[27] O. Gruzieva, A. Bergström, O. Hulchiy, I. Kull, T. Lind, E. Melén, et al., Exposure to Air Pollution from Traffic and Childhood Asthma Until 12 Years of Age, Epidemiology. 24 (2013) 54-61. doi:10.1097/EDE.0b013e318276c1ea.

[28] L. Modig, K. Torén, C. Janson, B. Jarvholm, B. Forsberg, Vehicle exhaust outside the home and onset of asthma among adults, Eur. Respir. J. 33 (2009) 1261-1267. doi:10.1183/09031936.00101108.

[29] D. Zmirou, S. Gauvin, I. Pin, I. Momas, F. Sahraoui, J. Just, et al., Traffic related air pollution and incidence of childhood asthma: results of the Vesta case-control study., J. Epidemiol. Community Health. 58 (2004) 18-23. doi:10.1136/jech.58.1.18.

[30] M. Shima, Y. Nitta, M. Adachi, Traffic-related air pollution and respiratory symptoms in children living along trunk roads in Chiba Prefecture, Japan, J. Epidemiol. 13 (2003) 108-119. http://cat.inist.fr/?aModele=afficheN\&cpsidt=14773739.

[31] T. Islam, R. McConnell, W.J. Gauderman, E. Avol, J.M. Peters, F.D. Gilliland, Ozone, Oxidant Defense Genes, and Risk of Asthma during Adolescence, Am. J. Respir. Crit. Care Med. 177 (2008) 388-395. doi:10.1164/rccm.200706-863OC. 
[32] T. Islam, K. Berhane, R. McConnell, W.J. Gauderman, E. Avol, J.M. Peters, et al., Glutathione-S-transferase (GST) P1, GSTM1, exercise, ozone and asthma incidence in school children., Thorax. 64 (2009) 197-202. doi:10.1136/thx.2008.099366.

[33] J.R. Greer, D.E. Abbey, R.J. Burchette, Asthma related to occupational and ambient air pollutants in nonsmokers., J. Occup. Med. 35 (1993) 909-15. http://www.ncbi.nlm.nih.gov/pubmed/8229343.

[34] W.F. McDonnell, D.E. Abbey, N. Nishino, M.D. Lebowitz, Long-term ambient ozone concentration and the incidence of asthma in nonsmoking adults: the AHSMOG Study., Environ. Res. 80 (1999) 110-121. doi:10.1006/enrs.1998.3894.

[35] N.A. Clark, P. a. Demers, C.J. Karr, M. Koehoorn, C. Lencar, L. Tamburic, et al., Effect of early life exposure to air pollution on development of childhood asthma, Environ. Health Perspect. 118 (2010) 284-290. doi:10.1289/ehp.0900916.

[36] S.E. Vieira, The health burden of pollution: the impact of prenatal exposure to air pollutants., Int. J. Chron. Obstruct. Pulmon. Dis. 10 (2015) 1111-21. doi:10.2147/COPD.S40214.

[37] M. Simoni, S. Baldacci, S. Maio, S. Cerrai, G. Sarno, G. Viegi, Adverse effects of outdoor pollution in the elderly., J. Thorac. Dis. 7 (2015) 34-45. doi:10.3978/j.issn.20721439.2014.12.10.

[38] J.E. Clougherty, A Growing Role for Gender Analysis in Air Pollution Epidemiology, Environ. Health Perspect. 118 (2009) 167-176. doi:10.1289/ehp.0900994.

[39] M.C. Turner, A. Cohen, M. Jerrett, S.M. Gapstur, W.R. Diver, C.A. Pope, et al., Interactions Between Cigarette Smoking and Fine Particulate Matter in the Risk of Lung Cancer Mortality in Cancer Prevention Study II, Am. J. Epidemiol. 180 (2014) 1145-1149. doi:10.1093/aje/kwu275.

[40] C. Janson, P. Kalm-Stephens, T. Foucard, K. Alving, S.L. Nordvall, Risk factors associated with allergic and non-allergic asthma in adolescents., Clin. Respir. J. 1 (2007) 16-22. doi:10.1111/j.1752-699X.2007.00001.x.

[41] T. Schikowski, E. Schaffner, F. Meier, H.C. Phuleria, A. Vierkötter, C. Schindler, et al., Improved air quality and attenuated lung function decline: Modification by obesity in the SAPALDIA cohort, Environ. Health Perspect. 121 (2013) 1034-1039. doi:10.1289/ehp.1206145.

[42] M. Adam, T. Schikowski, a. E. Carsin, Y. Cai, B. Jacquemin, M. Sanchez, et al., Adult lung function and long-term air pollution exposure. ESCAPE: a multicentre cohort study and metaanalysis, Eur. Respir. J. 45 (2015) 38-50. doi:10.1183/09031936.00130014.

[43] C.A. Camargo, S.T. Weiss, S. Zhang, W.C. Willett, F.E. Speizer, Prospective study of body mass index, weight change, and risk of adult-onset asthma in women., Arch. Intern. Med. 159 (1999) 2582-8. http://www.ncbi.nlm.nih.gov/pubmed/10573048.

[44] E. Morales, R. Garcia-Esteban, O. Asensio de la Cruz, M. Basterrechea, A. Lertxundi, M.D. Martinez López de Dicastillo, et al., Intrauterine and early postnatal exposure to outdoor air pollution and lung function at preschool age, Thorax. 70 (2015) 64-73. doi:10.1136/thoraxjnl2014-205413.

[45] P.F. Coogan, N. Castro-Webb, J. Yu, G.T. O'Connor, J.R. Palmer, L. Rosenberg, Active and Passive Smoking and the Incidence of Asthma in the Black Women's Health Study, Am. J. Respir. Crit. Care Med. 191 (2015) 168-176. doi:10.1164/rccm.201406-1108OC.

[46] M.J. Neidell, Air pollution, health, and socio-economic status: the effect of outdoor air quality on childhood asthma., J. Health Econ. 23 (2004) 1209-36. doi:10.1016/j.jhealeco.2004.05.002.

[47] F. Forastiere, M. Stafoggia, C. Tasco, S. Picciotto, N. Agabiti, G. Cesaroni, et al., Socioeconomic status, particulate air pollution, and daily mortality: differential exposure or differential susceptibility., Am. J. Ind. Med. 50 (2007) 208-16. doi:10.1002/ajim.20368.

[48] A. Hajat, A. V. Diez-Roux, S.D. Adar, A.H. Auchincloss, G.S. Lovasi, M.S. O'Neill, et al., Air pollution and individual and neighborhood socioeconomic status: evidence from the MultiEthnic Study of Atherosclerosis (MESA)., Environ. Health Perspect. 121 (2013) 1325-33. doi:10.1289/ehp.1206337.

[49] a Oosterlee, M. Drijver, E. Lebret, B. Brunekreef, Chronic respiratory symptoms in children and adults living along streets with high traffic density., Occup. Environ. Med. 53 (1996) 241- 
7. doi:10.1136/oem.53.4.241.

[50] R. McConnell, K. Berhane, L. Yao, M. Jerrett, F. Lurmann, F. Gilliland, et al., Traffic, susceptibility, and childhood asthma, Environ. Health Perspect. 114 (2006) 766-772. doi:10.1289/ehp.8594.

[51] S.D. Dell, M. Jerrett, B. Beckerman, J.R. Brook, R.G. Foty, N.L. Gilbert, et al., Presence of other allergic disease modifies the effect of early childhood traffic-related air pollution exposure on asthma prevalence, Environ. Int. 65 (2014) 83-92. doi:10.1016/j.envint.2014.01.002.

[52] S.H. Downs, C. Schindler, L.-J.S. Liu, D. Keidel, L. Bayer-Oglesby, M.H. Brutsche, et al., Reduced exposure to PM10 and attenuated age-related decline in lung function., N. Engl. J. Med. 357 (2007) 2338-47. doi:10.1056/NEJMoa073625.

[53] M. Rosenlund, F. Forastiere, D. Porta, M. De Sario, C. Badaloni, C. a Perucci, Traffic-related air pollution in relation to respiratory symptoms, allergic sensitisation and lung function in schoolchildren, Thorax. 64 (2009) 573-580. doi:10.1136/thx.2007.094953.

[54] E. Uphoff, B. Cabieses, M. Pinart, M. Valdés, J.M. Antó, J. Wright, A systematic review of socioeconomic position in relation to asthma and allergic diseases., Eur. Respir. J. 46 (2015) 364-74. doi:10.1183/09031936.00114514.

[55] A. Hajat, C. Hsia, M.S. O’Neill, Socioeconomic Disparities and Air Pollution Exposure: a Global Review, Curr. Environ. Heal. Reports. (2015). doi:10.1007/s40572-015-0069-5.

[56] I. Romieu, J.J. Sienra-Monge, M. Ramírez-Aguilar, M.M. Téllez-Rojo, H. Moreno-Macías, N.I. Reyes-Ruiz, et al., Antioxidant Supplementation and Lung Functions among Children with Asthma Exposed to High Levels of Air Pollutants, Am. J. Respir. Crit. Care Med. 166 (2002) 703-709. doi:10.1164/rccm.2112074.

[57] S.P. Eckel, T. a. Louis, P.H.M. Chaves, L.P. Fried, A.H.G. Margolis, L.P. Fried, et al., Modification of the Association Between Ambient Air Pollution and Lung Function by Frailty Status Among Older Adults in the Cardiovascular Health Study, Am. J. Epidemiol. 176 (2012) 214-223. doi:10.1093/aje/kws001.

[58] - M. Guarnieri, J.R. Balmes, Outdoor air pollution and asthma., Lancet. 383 (2014) 1581-92. doi:10.1016/S0140-6736(14)60617-6.

This review provides a complete overview of the association between air pollution and asthma in general, covering the association itself but also several others issues such as biological mechanism or risk modifiers.

[59] C. Liu, A. Maity, X. Lin, R.O. Wright, D.C. Christiani, Design and analysis issues in gene and environment studies., Environ. Health. 11 (2012) 93. doi:10.1186/1476-069X-11-93.

[60] M. Rava, I. Ahmed, F. Demenais, M. Sanchez, P. Tubert-Bitter, R. Nadif, Selection of genes for gene-environment interaction studies: a candidate pathway-based strategy using asthma as an example, Environ. Health. 12 (2013) 56. doi:10.1186/1476-069X-12-56. 
Table 1: Description of studies assessing the association between air pollution exposure and incident asthma in adults (by year of publication) and that had stratified their analyses by possible susceptibility factors

\begin{tabular}{|c|c|c|c|c|c|c|}
\hline $\begin{array}{l}\text { First author, } \\
\text { Year, Journal, } \\
\text { reference }\end{array}$ & $\begin{array}{l}\text { Design, Study, } \\
\text { Outcome }\end{array}$ & Population; age & Exposure assessment & Main association & $\begin{array}{l}\text { Susceptibility } \\
\text { factors }\end{array}$ & Modifying effect \\
\hline $\begin{array}{l}\text { Shima, 2003, J } \\
\text { Epidemiology } \\
{[30]}\end{array}$ & $\begin{array}{l}\text { Prospective } \\
\text { cohort study. } \\
\text { Recruitment in } \\
\text { 1992, follow-up } \\
\text { yearly until } 1995 . \\
\text { Outcome: } \\
\text { incident asthma. }\end{array}$ & $\begin{array}{l}1858 \text { children from } \\
8 \text { communities in } \\
\text { Chiba prefecture, } \\
\text { Japan. (6-9 years at } \\
\text { baseline) }\end{array}$ & $\begin{array}{l}\text { School proximity to } \\
\text { roadside: rural area, non- } \\
\text { roadside area: } \geq 50 \mathrm{~m} \text { from } \\
\text { the roads, roadside area: } \\
<50 \text { m from the roads. }\end{array}$ & $\begin{array}{l}\text { Symptoms of asthma } \\
\text { tended to increase in the } \\
\text { order of roadside }>\text { non- } \\
\text { road-side }>\text { rural areas. }\end{array}$ & Sex & $\begin{array}{l}\text {-Sex: Ref: rural area. } \\
\text { OR }(95 \% \mathrm{Cl}) \text { for non-roadside } \\
\text { area: } \\
1.99(0.79-4.99) \text { among boys, } \\
1.74(0.63-4.81) \text { among girls. } \\
\text { OR }(95 \% \mathrm{Cl}) \text { for roadside area: } \\
3.75(1.00-14.06) \text { among boys, } \\
4.06(0.91-18.10) \text { among girls. } \\
\text { Significant trend among boys } \\
\text { (p=0.013), not among girls }\end{array}$ \\
\hline $\begin{array}{l}\text { Zmirou, 2004, } \\
\text { JECH [29] }\end{array}$ & $\begin{array}{l}\text { Case control } \\
\text { study, conducted } \\
\text { in } 5 \text { French } \\
\text { metropolitan } \\
\text { areas: VESTA, } \\
\text { between } 1998 \\
\text { and } 2000 . \\
\text { Outcome: } \\
\text { incident asthma. }\end{array}$ & $\begin{array}{l}195 \text { pairs of } \\
\text { matched cases and } \\
\text { controls } \\
\text { investigated. Aged } \\
\text { 4-14 years }\end{array}$ & $\begin{array}{l}\text { Traffic density: time } \\
\text { weighted average of the } \\
\text { traffic density to road } \\
\text { distance ratio; index of } \\
\text { lifetime exposure to traffic } \\
\text { exhaust. Exposure index } \\
\text { considered in tertile. Home } \\
\text { and school addresses }\end{array}$ & $\begin{array}{l}\text { Traffic density associated } \\
\text { with asthma when } \\
\text { considering } 3 \text { first years of } \\
\text { life, but not when } \\
\text { averaging on life. OR } \\
\text { (95\%Cl) for traffic density } \\
\text { as a quantitative predictor: } \\
\text { 1.30(1.04-1.62). Results in } \\
\text { tertiles: ref=tertile1; } \\
\text { tertile2: } 1.48(0.73-3.02) \text {, } \\
\text { tertile3: } 2.28(1.14-4.56) \text {. }\end{array}$ & $\begin{array}{l}\text { Atopy (at least } \\
\text { one positive } \\
\text { SPT to one of } 9 \\
\text { tested } \\
\text { allergens) }\end{array}$ & $\begin{array}{l}\text {-Atopy (positive SPT). Tertile } 1 \\
\text { as reference. Atopic: Ter2: } \\
\text { 0.61(0.1-3.6), tertile3: } \\
\text { 11.03(1.3-100.9). Non-atopic: } \\
\text { Tert2: } 1.23(0.29-5.31) \text {, tert3: } \\
\text { 1.47(0.32-6.97) (p } \\
\text { interaction=0.20) }\end{array}$ \\
\hline $\begin{array}{l}\text { Pierse, 2006, } \\
\text { Thorax [11] }\end{array}$ & $\begin{array}{l}\text { Cohort study. } \\
\text { Recruitment in } \\
1998, \text { follow-up } \\
\text { in 2001. }\end{array}$ & $\begin{array}{l}4400 \text { children } \\
\text { recruited in } \\
\text { Lanceister. 1-5 } \\
\text { years at baseline. }\end{array}$ & $\begin{array}{l}\text { Annual exposure to } \mathrm{PM}_{10} \\
\text { (dispersion mode). Year of } \\
\text { exposure assessment: } 1998 \\
\text { and } 2001 \text { (mean of both }\end{array}$ & $\begin{array}{l}\text { Exposure to } \mathrm{PM}_{10} \text { and } \\
\text { incidence of asthma } \\
\text { symptoms: } 1.42(1.02-1.97) \\
\text { for wheeze (adjusted }\end{array}$ & $\begin{array}{l}\text { Age, } \\
\text { Secondhand- } \\
\text { smoke }\end{array}$ & $\begin{array}{l}\text { - Age: } 1.43(0.91-2.26) \text { in } \\
\text { children aged } 1-2.99 \text { years and } \\
1.39(0.86-2.25) \text { in children }\end{array}$ \\
\hline
\end{tabular}




\begin{tabular}{|c|c|c|c|c|c|c|}
\hline & $\begin{array}{l}\text { Outcome: } \\
\text { incident wheeze, } \\
\text { asthma } \\
\text { symptoms. }\end{array}$ & & years). Home addresses. & results) & & $\begin{array}{l}\text { aged 3-4.99years. } \\
\text {-Secondhand-smoke: ( } p \text { - } \\
\text { interact>0.1)" }\end{array}$ \\
\hline $\begin{array}{l}\text { Clougherty, } \\
2007, \text { EHP, } \\
{[12]}\end{array}$ & $\begin{array}{l}\text { Birth cohort, } \\
\text { recruitment: } \\
\text { between } 1987 \\
\text { and 1993, follow- } \\
\text { up in 1997. } \\
\text { Outcome: } \\
\text { incident asthma. }\end{array}$ & $\begin{array}{l}413 \text { children from } \\
\text { Boston, recruiting } \\
\text { pregnant women. }\end{array}$ & $\begin{array}{l}\text { Measured } \mathrm{NO}_{2} \text {, weekly } \\
\text { collected. Monthly } \\
\text { averaged, corresponding to } \\
\text { address of participants. } \\
\text { Year of exposure } \\
\text { assessment: Monthly from } \\
\text { January } 1987 \text { through } \\
\text { December } 2004\end{array}$ & $\begin{array}{l}\text { Univariate OR: } 1-\mathrm{SD} \\
\text { increase in year-of- } \\
\text { diagnosis of } \mathrm{NO}_{2} \text { showed } \\
\text { near-significant } \\
\text { associations with asthma: } \\
1.17(0.94-1.46) \text {. }\end{array}$ & $\begin{array}{l}\text { Exposure to } \\
\text { violence (ETV), }\end{array}$ & $\begin{array}{l}\text {-ETV: exposed above than } \\
\text { median: } 1.65(1.16-2.34), \text { lower } \\
\text { than median: } 0.94(0.70-1.26) \text {. } \\
\left.\text { (Year of diagnosis } \mathrm{NO}_{2}\right) . \\
\text { Multivariate: increase risk } \\
\text { among children with above } \\
\text { median ETV } 1.63(1.14-2.33) \\
\text { Above median: } 2.40(1.48-3.88)\end{array}$ \\
\hline $\begin{array}{l}\text { Islam et al., } \\
\text { 2008, AJRCCM, } \\
{[31]}\end{array}$ & $\begin{array}{l}\text { Prospective } \\
\text { cohort (CHS). } \\
\text { Recruitment } \\
\text { between } 1993 \\
\text { and } 2004 \text {, follow- } \\
\text { up yearly during } \\
\text { 2-8 years. } \\
\text { Outcome: } \\
\text { incident asthma. }\end{array}$ & $\begin{array}{l}1.125 \text { non- } \\
\text { Hispanic white and } \\
576 \text { Hispanic white } \\
\text { from } 12 \text { southern } \\
\text { California } \\
\text { communities.. } \\
\text { Age : }>7 \text { years. }\end{array}$ & $\begin{array}{l}\text { Average hourly levels of } \mathrm{O}_{3} \text {, } \\
\mathrm{NO}_{2} \text {, and } \mathrm{PM}\left(\mathrm{PM}_{10} \text { and }\right. \\
\mathrm{PM}_{2.5} \text { ). For ozone: annual } \\
\text { average of } 8 \text { h daytime } \\
\text { average computed } \\
\text { Communities were } \\
\text { classified as higher ozone } \\
\text { communities or lower } \\
\text { ozone communities. (1994- } \\
\text { 2003) }\end{array}$ & no general effect assessed & $\begin{array}{l}\text { Genetic } \\
\text { variants } \\
\text { MNSOD Ala- } \\
\text { 9Val (rs4880), } \\
\text { CAT-262C>T } \\
\text { (rs1001179), } \\
\text { and CAT- } \\
844 C<T \\
\text { (rs769214) } \\
\text { HMOX-1 (GT)n } \\
\text { repeats. Short } \\
\text { allele (S): }<23 \\
\text { repeats } \\
\text { ), race }\end{array}$ & $\begin{array}{l}\text {-Genetic: (GT)n repeat } \\
\text { polymorphism of } H M O X-1 \text { : } \\
\text { low-Ozone communities: } \\
\mathrm{HR}(95 \% \mathrm{Cl}) \text { : } 0.44(0.23-0.83 \text {; } \\
\text { high ozone communities } \\
\mathrm{HR}=0.88(0.33-2.34) \text {. P for } \\
\text { interaction }=0.003 \text {. } \\
\text { low-PM }_{10} \text { communities: } \mathrm{HR} \text { : } \\
0.94\left(0.54-1.62 ; \text { high } \mathrm{PM}_{10}\right. \\
\text { communities } \mathrm{HR}=0.62(0.20- \\
1.87) \text {. P for interaction }=0.18\end{array}$ \\
\hline $\begin{array}{l}\text { Nordling, } \\
\text { 2008, } \\
\text { Epidemiology, } \\
{[13]}\end{array}$ & $\begin{array}{l}\text { Birth cohort, } \\
\text { recruitment } \\
\text { between } 1994 \\
\text { and } 1996, \text { follow- } \\
\text { up at } 1,2 \text { and } 4 \\
\text { years of age. } \\
\text { Outcome: } \\
\text { Persistent }\end{array}$ & $\begin{array}{l}4089 \text { infants from } \\
4 \text { Swedish } \\
\text { Municipalities. Age } \\
\text { different according } \\
\text { to the follow-up (1, } \\
2 \text { and } 4 \text { year-old). }\end{array}$ & $\begin{array}{l}\text { Dispersion model. NOx, } \\
\mathrm{PM}_{10} \text {, SO2. Home } \\
\text { addresses. 1990: traffic } \\
\text { NOx and heating SO2. } \\
\text { 2000: traffic NOx, heating } \\
\text { SO2 and traffic } \mathrm{PM}_{10} \text {. } \\
\text { Outdoor levels of air } \\
\text { pollution for the children's }\end{array}$ & $\begin{array}{l}\text { Persistent wheezing: } \\
\text { Association with traffic NOx } \\
\text { (for a difference between } \\
\text { the } 5 \text { th and } 95 \text { th percentile } \\
\text { range in the cohort): OR: } \\
1.60(1.09-2.36) \text {. Similar but } \\
\text { ns results for } \mathrm{PM}_{10} \text {. No } \\
\text { association between }\end{array}$ & $\begin{array}{l}\text { Age, Atopy } \\
\text { (atopic wheeze: } \\
\text { allergic } \\
\text { sensitization to } \\
\text { pollen (specific- } \\
\text { IgE)) }\end{array}$ & $\begin{array}{l}\text {-Sex: persistent wheezing: } \\
\text { girls: OR: } 1.94(1.07-3.50) \text {, boys: } \\
\text { OR: } 1.55(0.92-2.63) \\
\text {-Atopy: persistent-wheezing } \\
\text { and late-onset: non-atopic } \\
\text { wheeze: NOx: } 1.46(1.00- \\
\text { 2.13),atopic wheeze: NOx: } \\
\text { 1.11(0.55-2.22).(p- }\end{array}$ \\
\hline
\end{tabular}




\begin{tabular}{|c|c|c|c|c|c|c|}
\hline & $\begin{array}{l}\text { wheezing and } \\
\text { late-onset } \\
\text { asthma }\end{array}$ & & $\begin{array}{l}\text { first year of life (1994- } \\
\text { 1997): interpolation from } \\
\text { the data of } 1999 \text { and } 2000\end{array}$ & $\begin{array}{l}\text { pollutant and late-onset } \\
\text { asthma }\end{array}$ & & interaction $=0.43$ ) \\
\hline $\begin{array}{l}\text { Islam, 2009, } \\
\text { Thorax, [32] }\end{array}$ & $\begin{array}{l}\text { Prospective } \\
\text { cohort (CHS). } \\
\text { Recruitment } \\
\text { between } 1993 \\
\text { and } 2004 \text {, follow- } \\
\text { up yearly during } \\
\text { 2-8 years. } \\
\text { Outcome: } \\
\text { incident asthma. }\end{array}$ & $\begin{array}{l}1064 \text { non-Hispanic } \\
\text { white and } 576 \\
\text { Hispanic white } \\
\text { from } 12 \text { southern } \\
\text { California } \\
\text { communities. Age: } \\
>7 \text { years. }\end{array}$ & $\begin{array}{l}\text { Average hourly levels of } \\
\text { zone }\left(\mathrm{O}_{3}\right) \text {, nitrogen dioxide } \\
\left(\mathrm{NO}_{2}\right) \text {, and particulate } \\
\text { matter }\left(\mathrm{PM}_{10} \text { and } \mathrm{PM}_{2.5}\right) \\
\text { For ozone: annual average } \\
\text { of 8h daytime average } \\
\text { computed } \\
\text { Communities were } \\
\text { classified as higher ozone } \\
\text { communities or lower } \\
\text { ozone communities. Years } \\
\text { of exposure assessment: } \\
\text { 1994-2003. }\end{array}$ & none & $\begin{array}{l}\text { Genetic } \\
\text { variants } \\
\text { GSTP1 } \\
\text { haplotype } \\
\text { tagging SNPs: } \\
\text { rs6591255, } \\
\text { rs4147581 and } \\
\text { lle105Val and } \\
\text { rs749174 } \\
\text { GSTM1 null } \\
\text { genotype } \\
\text { CAT-262C>T } \\
\text { (rs1001179) } \\
\text { and HMOX-1 } \\
\text { (GT)n repeats. } \\
\text { Short allele } \\
\text { (S):<23 } \\
\text { repeats), sport } \\
\text { played }\end{array}$ & $\begin{array}{l}\text {-Genetic: risk of new onset } \\
\text { asthma among lle105 } \\
\text { homozygotes in high ozone } \\
\text { community: HR (6.15; } 2.2-7.4 \text {, } \\
\text { P for interaction=0.10, limited } \\
\text { sample size) } \\
\text { lle105 homozygotes in low } \\
\text { ozone community: } 1.06(0.3- \\
4.0) \\
\text { [among those who played >2 } \\
\text { team sports, no difference } \\
\text { among those playing less than } \\
2 \text { sports] }\end{array}$ \\
\hline $\begin{array}{l}\text { Oftedal, 2009, } \\
\text { EHP, [14] }\end{array}$ & $\begin{array}{l}\text { Oslo Birth Cohort. } \\
\text { Recruitment in } \\
\text { 1992-1993, } \\
\text { follow-up: 2001- } \\
2002 \text { (and cross } \\
\text { sectional study). } \\
\text { Outcome: } \\
\text { incident asthma. }\end{array}$ & $\begin{array}{l}2871 \text { children born } \\
\text { in Oslo. }\end{array}$ & $\begin{array}{l}\mathrm{NO}_{2} \text { dispersion model. } \\
\text { Home addresses }\end{array}$ & $\begin{array}{l}\text { No positive associations } \\
\text { between any long-term } \\
\text { TRAP and onset of doctor- } \\
\text { diagnosed asthma. (but a } \\
\text { negative association) } \\
\text { Associations for late } \\
\text { asthma onset (>4years of } \\
\text { age) was positive but NS. }\end{array}$ & Sex & $\begin{array}{l}\text {-Sex: RR of } 0.73(0.56-0.95) \text { in } \\
\text { boys and } 1.05(0.74-1.49) \text { in } \\
\text { girls }(p \text {-interaction }=0.10)\end{array}$ \\
\hline $\begin{array}{l}\text { Shankardass, } \\
\text { 2009, PNAS, } \\
{[15]}\end{array}$ & $\begin{array}{l}\text { Prospective } \\
\text { cohort study } \\
\text { (CHS). } \\
\text { Recruitment: } \\
\text { 2002-2003 and }\end{array}$ & $\begin{array}{l}2497 \text { children from } \\
13 \text { southern } \\
\text { California } \\
\text { communities, aged } \\
5-9 \text { years at }\end{array}$ & $\begin{array}{l}\text { NOx dispersion model. } \\
\text { Annual concentrations. } \\
\text { Home address. Year of } \\
\text { exposure assessment: } \\
1997 .\end{array}$ & $\begin{array}{l}\text { Risk of asthma increased } \\
\text { with exposure to Traffic } \\
\text { Related Pollution: } \\
\mathrm{HR}(95 \% \mathrm{CI}) 1.31 \text { (1.07- } \\
1.61) \text {, for an IQR of } 21 \mathrm{ppb}\end{array}$ & $\begin{array}{l}\text { Parental stress, } \\
\text { SES }\end{array}$ & $\begin{array}{l}\text {-Parental stress ( } p \text { interaction } \\
0.05) \text { : High parental stress: HR: } \\
\text { 1.51(1.16-1.96) Low parental } \\
\text { stress: } 1.05(0.74-1.49) . p- \\
\text { interact for 3way "gender- }\end{array}$ \\
\hline
\end{tabular}


follow-up during

baseline.

3 years.

Outcome:

incident asthma. of NOx

parental stress-air

pollution"=0.10): High parental

stress: Men: 1.60(1.16-2.22),

Women: 1.36(0.87-2.11). Low

parental stress: Men:

0.98(0.61-1.59), women:

1.14(0.68-1.90)

-SES: ( $p$ interaction 0.25): High

SES: 1.20(0.93-1.55). Low-SES:

1.55(1.09-2.19)

EHP, [35]

\begin{tabular}{|c|c|c|}
\hline $\begin{array}{l}\text { Nested case- } \\
\text { control in a } \\
\text { Cohort study, all } \\
1999 \text { and } 2000 \\
\text { births in British } \\
\text { Columbia } \\
\text { (Canada). } \\
\text { Outcome: }\end{array}$ & $\begin{array}{l}3482 \text { cases and } \\
17410 \text { controls, } \\
\text { among } 37401 \\
\text { children. } 36-59 \\
\text { months at the end } \\
\text { of the follow-up }\end{array}$ & $\begin{array}{l}\text { LUR modeling/IDW. High } \\
\text { resolution (10m) TRAP: NO, } \\
\mathrm{NO}_{2}, \mathrm{PM}_{2.5} \text {, black carbon. } \\
\text { Exposure levels assigned at } \\
\text { the zip code level. Average } \\
\text { exposure calculated for } \\
\text { duration of pregnancy and } \\
\text { first year of life. }\end{array}$ \\
\hline $\begin{array}{l}\text { Prospective birth } \\
\text { cohort (PIAMA). } \\
\text { Recruitment in } \\
\text { 1996-1997 of } \\
\text { pregnant women, } \\
\text { follow-up yearly } \\
\text { during } 8 \text { years). } \\
\text { Outcome: }\end{array}$ & $\begin{array}{l}3863 \text { Netherlands } \\
\text { children }\end{array}$ & $\begin{array}{l}\text { LUR. } \mathrm{NO}_{2}, \mathrm{PM}_{2.5} \text {, soot: four } \\
\text { times 2-week } \\
\text { measurement in a year } \\
\text { and then adjustment on } \\
\text { temporal trend to calculate } \\
\text { long-term average } \\
\text { concentrations. Birth } \\
\text { address. }\end{array}$ \\
\hline
\end{tabular}

Clark, 2010,

Increased risk of asthma

diagnosis with increased

early life exposure (in utero

results for $1^{\text {st }}$ year of life).

OR for 1st year of life:

1.08(1.04-1.12) for a

$10 \mathrm{mg} \cdot \mathrm{m}^{3}{ }^{3}$ increase of NO,

1.12(1.07-1.17) for a

$10 \mathrm{mg} \cdot \mathrm{m}^{-3}$ increase of $\mathrm{NO}_{2}$,

$1.10(1.06-1.13)$ for a

$100 \mathrm{mg} \cdot \mathrm{m}^{3}{ }^{3}$ increase of $\mathrm{CO}$,

1.07(1.03-1.12) for an

increase of $1 \mathrm{mg} . \mathrm{m}^{3}{ }^{3}$ in

$\mathrm{PM}_{10}$.

Gehring, 2010,

AJRCCM, [16]

incident asthma.
Association between $\mathrm{PM}_{2.5}$ concentration and incidence of asthma: 1.28(1.10-1.49) (same results for $\mathrm{NO}_{2}$ and soot) and $1^{\text {st }}$ year of life. Greater
Sex, Definition - Sex:

of asthma

NO: 1.13(1.06-1.20) for girls and 1.05(1.00-1.10) for boys. $\mathrm{NO}_{2}$ : 1.17(1.09-1.26) for girls and $1.09(1.03-1.16)$ for boys
Atopy (Spécific-

$\operatorname{IgE}$ to 6

allergens), Age
Non-adjusted models (due to small sample size)

-Atopy: Non atopic: $\mathrm{NO}_{2}, \mathrm{PM}_{2.5}$ and soot: 1.85(0.92-3.73), 2.98(1.21-7.37), and 2.06(0.99-

4.3). Atopic: $\mathrm{NO}_{2}, \mathrm{PM}_{2.5}$ and soot: $0.95(0.64-1.40)$,

$1.00(0.63-1.58)$, and

$0.97(0.641 .46)$.

-Age: effect of air pollution on 


\begin{tabular}{|c|c|c|c|c|c|c|}
\hline & & & & & & $\begin{array}{l}\text { incidence of asthma was } \\
\text { stronger at ages } 6 \text {-8years } \\
(\mathrm{OR} \approx 1.6, \text { significant at } 8, \mathrm{NS} \text { at } \\
7 \text { and borderline at } 6 \\
\text { compared to } \mathrm{OR} \approx 1.2 \text { NS for } \\
\text { younger age. Results available } \\
\text { in a figure) }\end{array}$ \\
\hline $\begin{array}{l}\text { Carlsten, 2011, } \\
\text { OEM, [17] }\end{array}$ & $\begin{array}{l}\text { Intervention } \\
\text { prenatally study. } \\
\text { Recruitment } \\
\text { during pregnancy } \\
\text { in } 1995 \text {, follow up } \\
\text { until } 7 \text { years of } \\
\text { age. Outcome: } \\
\text { incident asthma. }\end{array}$ & $\begin{array}{l}184 \text { children from } \\
\text { Vancouver, at } \\
\text { high-risk for } \\
\text { asthma }\end{array}$ & $\begin{array}{l}\text { LUR. } \mathrm{NO}, \mathrm{NO}_{2} \text {, black carbon } \\
\text { and } \mathrm{PM}_{2.5} \text {. Year of exposure } \\
\text { assessment: } 2003 \text {, } \\
\text { exposure of birth year } \\
\text { estimated. Residential } \\
\text { address }\end{array}$ & $\begin{array}{l}\text { Elevation in exposure to } \\
\text { some Traffic Related Air } \\
\text { Pollution during the year of } \\
\text { birth are associated with } \\
\text { new onset asthma at } 7 . \\
\text { Results by quartile. } \\
\text { Significant for last quartile, } \\
\text { only for PM } M_{2.5} \text {. No } \\
\text { significant results for the } \\
\text { others pollutants, despite } \\
\text { the increase. }\end{array}$ & Sex, Race & $\begin{array}{l}\text { Suggestion of increased in mer } \\
\text { (data not shown) } \\
\text { Suggestion of increased in } \\
\text { Caucasian (data not shown) }\end{array}$ \\
\hline $\begin{array}{l}\text { Gruzieva, } \\
2013, \\
\text { Epidemiology, } \\
{[27]}\end{array}$ & $\begin{array}{l}\text { Swedish Birth } \\
\text { cohort BAMSE. } \\
\text { Recruitment } \\
\text { between } 1994 \\
\text { and 1996, follow } \\
\text { up during } 12 \\
\text { years. Outcome: } \\
\text { incident wheeze, } \\
\text { incident asthma. }\end{array}$ & 4089 children. & $\begin{array}{l}\text { Gaussian dispersion model } \\
\text { and wind model used to } \\
\text { assess concentration of } \\
\mathrm{PM}_{10} \text { and NOx. Years of } \\
\text { exposure assessment: } 1994 \\
\text { to 1998. Interpolation of } \\
\text { concentrations for some } \\
\text { years for NOx. Residential, } \\
\text { daycare and school } \\
\text { addresses. }\end{array}$ & $\begin{array}{l}\text { Incidence of wheeze } \\
\text { symptoms seems to be } \\
\text { highest during the first } 2 \\
\text { years of life. Associations } \\
\text { between exposure to NOx } \\
\text { or } \mathrm{PM}_{10} \text { and incident } \\
\text { asthma over the first } 12 \\
\text { years of life: OR: } 1.21 \\
(0.79-1.84) \text { for NOx, OR: } \\
1.34(0.80-2.23) \text { for PM } \\
\text { Results significant only at } \\
\text { age } 12 \text {. }\end{array}$ & $\begin{array}{l}\text { Sex, } \\
\text { Allergic/Non- } \\
\text { allergic asthma } \\
\text { (atopy assessed } \\
\text { by specific-lgE } \\
\text { to } 8 \text { allergens), } \\
\text { Age }\end{array}$ & 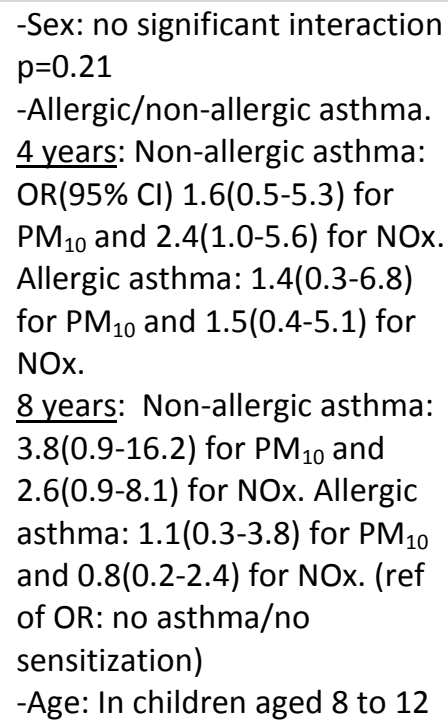 \\
\hline
\end{tabular}




\begin{tabular}{|c|c|c|c|c|c|c|}
\hline & & & & & & $\begin{array}{l}\text { years: } 2.0(1.1-3.5) \\
\text { Incident asthma ORs: } \\
1 \text { years: } 0.85(0.44-1.62) \text { for } \\
\text { NOx and } 0.79(0.39-1.62) \text { for } \\
\text { PM }_{10} \\
2 \text { years: } 0.96(0.51-1.80) \text { for } \\
\text { NOx and } 1.14(0.57-2.25) \text { for } \\
\text { PM }_{10} \\
4 \text { years: } 1.48(0.85-2.57) \text { for } \\
N^{2} \text { ax and } 1.59(0.83-3.05) \text { for } \\
\text { PM }_{10} \\
8 \text { years: } 1.07(0.53-2.14) \text { for } \\
N^{2} \text { ax and } 1.30(0.61-2.74) \text { for } \\
\text { PM }_{10} \\
12 \text { years: } 1.87(1.01-3.44) \text { for } \\
N^{2} \text { ax and } 2.39(1.18-4.86) \text { for } \\
\text { PM }_{10}\end{array}$ \\
\hline $\begin{array}{l}\text { Nishimura, } \\
\text { 2013, AJRCCM, } \\
{[18]}\end{array}$ & $\begin{array}{l}\text { GALA II (case } \\
\text { control) and } \\
\text { SAGE II. } \\
\text { Recruitment } \\
\text { between } 2006 \\
\text { and } 2011 . \\
\text { Outcome: } \\
\text { incident asthma. }\end{array}$ & $\begin{array}{l}\text { Latinos from urban } \\
\text { regions in USA and } \\
\text { Puerto Rico and } \\
\text { African Americans } \\
\text { from SF bay, } 3343 \\
\text { Latinos and } 977 \\
\text { African American, } \\
\text { with no history of } \\
\text { other lung or } \\
\text { chronic illness. 8- } \\
21 \text { years }\end{array}$ & $\begin{array}{l}\mathrm{O}_{3}, \mathrm{NO}_{2}, \mathrm{SO}_{2}, \mathrm{PM}_{10}, \mathrm{PM}_{2.5} \\
\text { Inverse distance-squared } \\
\text { weighted average. } \\
\text { Residence address. } \\
\text { Exposure over the first } 3 \\
\text { years of life. }\end{array}$ & $\begin{array}{l}\text { A } 5 p p b \text { increase in } \mathrm{NO}_{2} \\
\text { during the first year of life } \\
\text { associated with incident } \\
\text { asthma: } \mathrm{OR}(95 \% \mathrm{Cl}) \text { for first } \\
\text { year of life: } \mathrm{OR}_{1}: 1.17(1.04- \\
1.31) \text {. OR( } 95 \% \mathrm{Cl}) \text { for first } \\
\text { three year of life: } \\
\mathrm{OR}_{3}: 1.26(1.07-1.48) \text {. NS for } \\
\mathrm{PM} \text { and } \mathrm{O}_{3}\end{array}$ & Sex, Total-IgE & $\begin{array}{l}\text { - Sex: } \\
\mathrm{NO}_{2} \text { : } \\
\mathrm{OR}_{1}: 1.26(1.05-1.52) \text { in boys, } \\
1.11(0.96-1.29) \text { in girls; } \\
\mathrm{OR}_{3}: 1.47(1.05-1.52) \text { in boys, } \\
1.24(1.02-1.50) \text { in girls. } \\
\mathrm{PM}_{10}: \\
\mathrm{OR}_{1}: 1.10(0.89-1.36) \text { in boys, } \\
1.15(0.97-1.37) \text { in girls ; } \\
\mathrm{OR}_{3}: 1.08(0.86-1.35) \text { in boys, } \\
1.19(1.00-1.41) \text { in girls. } \\
\mathrm{PM}_{2.5}: \\
\mathrm{OR}_{1}: 0.92(0.73-1.16) \text { in boys, } \\
1.13(0.98-1.30) \text { in girls; } \\
\mathrm{OR}_{3}: 0.91(0.77-1.06) \text { in boys, } \\
1.15(1.02-1.30) \text { in girls. } \\
\text { all p for interaction NS } \\
- \text { Total IgE }\end{array}$ \\
\hline
\end{tabular}




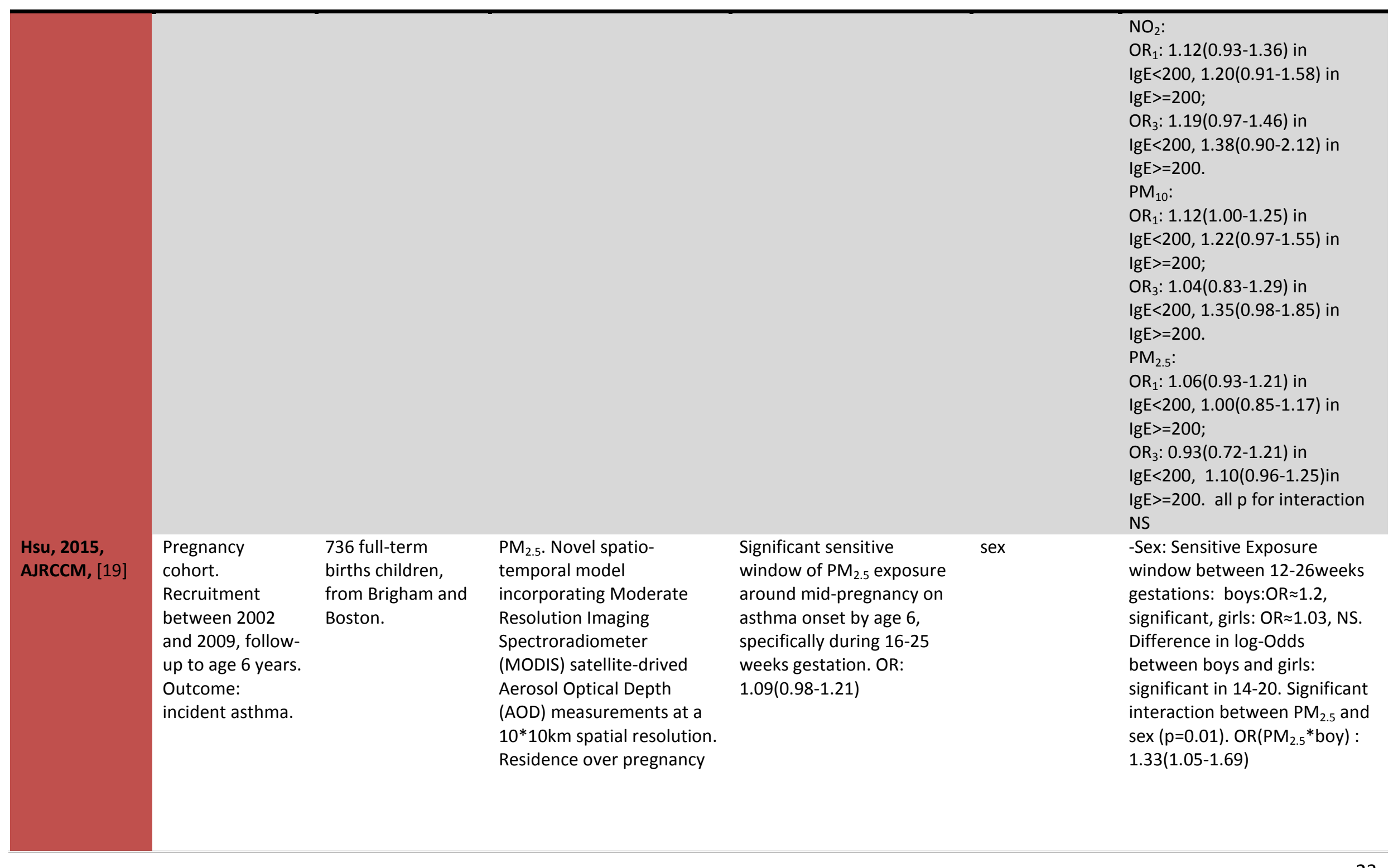


Abbreviations: OR: Odds Ratio, RR: Risk Ratio, HR: Hazard Ratio, Cl: Confidence Interval, PM: Particule Matter, $\mathrm{NO}_{2}$ : Nitrogen dioxyde, NOx: Nitrogen oxide,

O3 ozone, IgE: Immunoglobulin E, SPT: Skin Prick Test, BHR: Bronchial Hyper Reactivity, NS: not significant, TRAP: Traffic Related Air Pollution 
Table 2: Description of studies assessing the association between air pollution exposure and incident asthma or wheeze in children (by year of publication) and that had stratified their analyses by possible susceptibility factors

\begin{tabular}{|c|c|c|c|c|c|c|}
\hline $\begin{array}{l}\text { First author, } \\
\text { Year, Journal, } \\
\text { Reference }\end{array}$ & $\begin{array}{l}\text { Design, Study, } \\
\text { follow-up }\end{array}$ & Population; age & Exposure assessment & Main association & $\begin{array}{l}\text { Susceptibility } \\
\text { factors }\end{array}$ & Modifying effects \\
\hline $\begin{array}{l}\text { Greer, 1993, } \\
\text { JOM, [33] }\end{array}$ & $\begin{array}{l}\text { Prospective } \\
\text { Cohort } \\
\text { (California), } \\
\text { AHSMOG. } \\
\text { Recruitment in } \\
\text { 1977, follow-up in } \\
1987 .\end{array}$ & $\begin{array}{l}3577 \text { non- } \\
\text { smokers } \\
\text { seventh-day } \\
\text { Adventist. Mean } \\
\text { age: } 27-87 \text { years. }\end{array}$ & $\begin{array}{l}\text { Monthly interpolations of } \mathrm{O3} \\
\text { from fixed-site monitoring } \\
\text { stations applied to residential } \\
\text { addresses and work site. Year of } \\
\text { exposure assessment: } 1987 .\end{array}$ & $\begin{array}{l}\text { Borderline association of } \\
\text { increased risk of asthma } \\
\text { associated with increased } \\
\text { ambient concentrations } \\
\text { of ozone exposure } \\
\text { (RR=1.31, Cl: } 0.96-1.78)\end{array}$ & Sex & $\begin{array}{l}\text {-Sex: increase in ambient } \\
\text { concentrations of ozone } \\
\text { exposure (Mean ozone } \\
\text { concentration exposure } \\
\text { through 1987)RR: } 3.12, \mathrm{Cl} \text { : } \\
1.61-5.85 \text { in men, RR: } 0.94 \\
\text { "not significant at } 0.05 \\
\text { level" in women) }\end{array}$ \\
\hline $\begin{array}{l}\text { McDonnell, } \\
\text { 1999, } \\
\text { Environmental } \\
\text { Research, [34] }\end{array}$ & $\begin{array}{l}\text { Prospective } \\
\text { Cohort } \\
\text { (California), } \\
\text { AHSMOG. } \\
\text { Recruitment in } \\
\text { 1977, follow-up in } \\
1987 .\end{array}$ & $\begin{array}{l}3091 \text { non- } \\
\text { smokers } \\
\text { seventh-day } \\
\text { Adventist (101 } \\
\text { cases). Mean- } \\
\text { age: } 27-87 \text { years }\end{array}$ & $\begin{array}{l}\mathrm{O}_{3}, \mathrm{PM}_{10}, \mathrm{SO}_{4}, \mathrm{NO}_{2}, \mathrm{SO}_{2} . \\
\text { Exposure concentrations } \\
\text { interpolated to zip code } \\
\text { according to home and work } \\
\text { location, cumulated and } \\
\text { averaged over time. For ozone } \\
\text { and } \mathrm{PM}_{10} \text { : alternative indices: } \\
\text { 8h-average ozone concentration } \\
\text { (work hours) Years of exposure } \\
\text { assessment: } 1973-1992 \text {. }\end{array}$ & $\begin{array}{l}\text { 20years } \mathrm{O}_{3}-8 \text { h average } \\
\text { associated with report of } \\
\text { doctor diagnosis of } \\
\text { asthma: RR } 2.09(1.03- \\
4.16)\end{array}$ & $\begin{array}{l}\text { Sex, smoking } \\
\text { status }\end{array}$ & $\begin{array}{l}\text {-Sex: Men: RR: } 2.09(1.03- \\
\text { 4.16), Women: } 0.86(0.58- \\
1.26) \\
\text {-Smoking: Similar } \\
\text { association for ex-smoking } \\
\text { and never-smoking. }\end{array}$ \\
\hline $\begin{array}{l}\text { Modig, 2006, } \\
\text { ERJ, [20] }\end{array}$ & $\begin{array}{l}\text { Case-control } \\
\text { study. } \\
\text { Recruitment } \\
\text { between } 1995 \\
\text { and } 1999 .\end{array}$ & $\begin{array}{l}203 \text { cases } / 203 \\
\text { sex and age- } \\
\text { matched } \\
\text { controls from } \\
\text { Lulea, Sweden. } \\
20-60 \text { years }\end{array}$ & $\begin{array}{l}\text { Home outdoor NO2 } \\
\text { measurements for } 1 \text { week, } \\
\text { standardized and adjusted to } \\
\text { represent annual average (for } \\
\text { the year of recruitment).Traffic } \\
\text { intensity at home address. Years } \\
\text { of exposure assessment: 1999- } \\
2000 \text {. }\end{array}$ & $\begin{array}{l}\text { No association between } \\
\text { NO2 level and asthma } \\
\text { incidence (OR: } 1.1(0.9- \\
\text { 1.2)). Living close to high } \\
\text { traffic was non- } \\
\text { significantly associated } \\
\text { with asthma incidence. }\end{array}$ & $\begin{array}{l}\text { Atopy (defined } \\
\text { as positive SPT : } \\
\text { no more details) }\end{array}$ & $\begin{array}{l}\text {-Atopy: [Among those who } \\
\text { live }>2 \text { years in the present } \\
\text { home]: OR for an increase } \\
\text { of } 1 \mathrm{mg} \cdot \mathrm{m}^{-3} \text { of NO2: }>0 \text { SPT } \\
1.2(1.0-1.3) ;<0 \text { SPT: } \\
1.0(0.9-1.1) \text {. }\end{array}$ \\
\hline
\end{tabular}




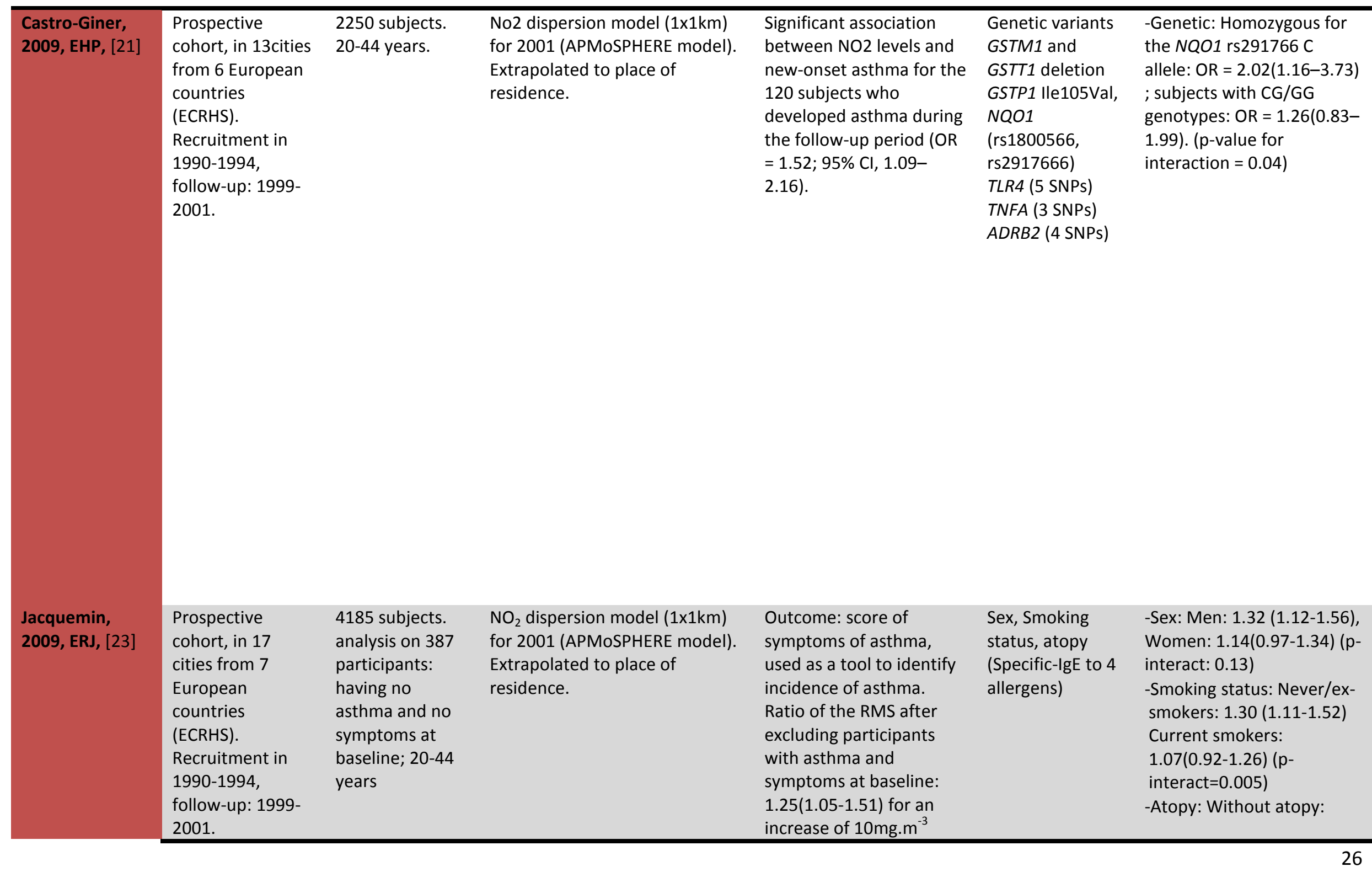




\begin{tabular}{|c|c|c|c|c|c|c|}
\hline & & & & & & $\begin{array}{l}1.20(1.02-1.41) \text { With } \\
\text { atopy: } 1.37(1.14-1.65)(p- \\
\text { interact }=0.63)\end{array}$ \\
\hline $\begin{array}{l}\text { Jacquemin, } \\
2009, \\
\text { Epidemiology, } \\
{[22]}\end{array}$ & $\begin{array}{l}\text { Prospective } \\
\text { cohort, in } 17 \\
\text { cities from } 7 \\
\text { European } \\
\text { countries } \\
\text { (ECRHS). } \\
\text { Recruitment in } \\
\text { 1990-1994, } \\
\text { follow-up: 1999- } \\
\text { 2001. }\end{array}$ & $\begin{array}{l}4185 \text { subjects. } \\
20-44 \text { years }\end{array}$ & $\begin{array}{l}\mathrm{NO}_{2} \text { dispersion model }(1 \times 1 \mathrm{~km}) \\
\text { for } 2001 \text { (APMoSPHERE model). } \\
\text { Extrapolated to place of } \\
\text { residence. }\end{array}$ & $\begin{array}{l}\text { Positive association } \\
\text { between NO2 and } \\
\text { asthma incidence } \\
(1.43(1.02-2.01) \text { per } \\
10 \mathrm{mg} \cdot \mathrm{m}^{-3} \text { When known } \\
\text { age of asthma onset } \\
\text { between the } 2 \text { surveys: } \\
1.72(0.99-3.00)\end{array}$ & $\begin{array}{l}\text { Sex, Atopy } \\
\text { (Specific-IgE to } 4 \\
\text { allergens) }\end{array}$ & $\begin{array}{l}\text {-Sex: OR per } 10 \mathrm{mg} \cdot \mathrm{m}^{-3} \\
\text { increased of NO2: Men: } \\
1.31(0.76-2.27) . \text { Women: } \\
1.53(0.99-2.38)(\mathrm{p}- \\
\text { interact }=0.69) \\
\text {-Atopy: OR: } 1.31(0.84-2.04) \\
\text { per } 10 \mathrm{mg} \cdot \mathrm{m}^{-3} \text { increased of } \\
\text { NO2. } \\
\text { No atopy: } 1.57(0.92-2.67) \\
\text { (p-interact }=0.77)\end{array}$ \\
\hline $\begin{array}{l}\text { Künzli, 2009, } \\
\text { Thorax, [24] }\end{array}$ & $\begin{array}{l}\text { Prospective } \\
\text { cohort in } 8 \text { Swiss } \\
\text { Areas (SAPALDIA). } \\
\text { Recruitment in } \\
1990-91 \text { and } \\
\text { follow-up in } 2002 .\end{array}$ & $\begin{array}{l}2725 \text { never } \\
\text { smokers, } \\
\text { without asthma } \\
\text { or COPD. 18-60 } \\
\text { years. }\end{array}$ & $\begin{array}{l}\text { Traffic related } \mathrm{PM}_{10} \text { (particle } \\
\left.\text { matter up to } 10 \mathrm{mg}^{-3} \mathrm{~m}^{-3} \mathrm{TPM}_{10}\right) \\
\text { change, from } 1990 \text { and } 2000 \\
\text { using dispersion model. } \\
\text { Exposure interpolated at } \\
\text { participants place. }\end{array}$ & $\begin{array}{l}\text { Incidence of asthma was } \\
\text { associated with a change } \\
\text { in } \mathrm{PM}_{10} \text { in never-smoker. } \\
\mathrm{HR}: 1.30(1.05-1.61) \text { per } \\
1 \mathrm{mg} \cdot \mathrm{m}^{-3} \text { change in } \mathrm{PM}_{10}\end{array}$ & $\begin{array}{l}\text { Sex, Atopy (SPT } \\
\text { to } 8 \text { allergens), } \\
\text { Age, parental } \\
\text { asthma, parental } \\
\text { allergy, BHR, } \\
\text { smoking status }\end{array}$ & 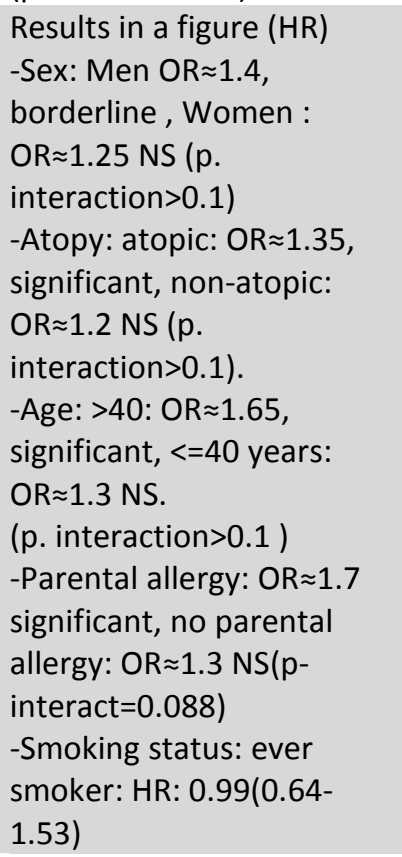 \\
\hline Modig, 2009, & Prospective & 3609 & NO2 dispersion models & Association between per & Sex, atopy (hay & -Sex: OR for $\mathrm{NO}_{2}$ per \\
\hline
\end{tabular}




\begin{tabular}{|c|c|c|c|c|c|c|}
\hline ERJ, [28] & $\begin{array}{l}\text { cohort, } 3 \text { Swedish } \\
\text { cities (RHINE). } \\
\text { Recruitment in } \\
\text { 1990, follow-up in } \\
\text { 1999. }\end{array}$ & $\begin{array}{l}\text { participants. } 18- \\
45 y e a r s\end{array}$ & $\begin{array}{l}(50 \times 50 \mathrm{~m}) \text {, distance to major } \\
\text { road<50m. Both estimates at } \\
\text { home address. Year of exposure } \\
\text { assessment: } 1990 .\end{array}$ & $\begin{array}{l}10 \mathrm{mg} \cdot \mathrm{m}^{-3} \text { increase in } \mathrm{NO} 2 \\
\text { and incident asthma } \\
(1.54(1.00-2.36) \\
\text { Risk of developing } \\
\text { asthma related to living } \\
\text { close to a major road: } \\
3.88(1.93-7.82)\end{array}$ & fever as proxy) & $\begin{array}{l}10 \mathrm{mg} \cdot \mathrm{m}^{-3}: \text { Women: } \\
1.67(0.98-2.74), \text { Men: } \\
1.32(0.64-2.74) \text { ( } p- \\
\text { interact }=0.63) \\
\text {-Hay fever status: OR for } \\
\text { NO2 per } 10 \mathrm{mg} \cdot \mathrm{m}^{-3} \text { : } \\
\text { Subject with hay fever: } \\
1.15(0.59-2.24) \\
\text { Subject without hay fever: } \\
1.79(1.04-3.05) \text { a ( } p- \\
\text { interact }=0.30)\end{array}$ \\
\hline $\begin{array}{l}\text { Young, 2014, } \\
\text { AJRCCM, [25] }\end{array}$ & $\begin{array}{l}\text { Sister study, } \\
\text { cohort. } \\
\text { Recruitment: } \\
\text { 2003-2009, } \\
\text { follow-up 2008- } \\
2012\end{array}$ & $\begin{array}{l}50884 \text { US sisters } \\
\text { of women with } \\
\text { breast cancer, } \\
\text { mean age: } 55 \text {. }\end{array}$ & $\begin{array}{l}\mathrm{PM}_{2.5} \text { and } \mathrm{NO}_{2} \text {. National land- } \\
\text { use/kriging model incorporating } \\
\text { roadway information. Addresses } \\
\text { of the participants geocoded. } \\
\text { Year of exposure assessment: } \\
2006 \text {. }\end{array}$ & $\begin{array}{l}\text { OR of incident asthma for } \\
\text { an IQR increase of } \mathrm{PM}_{2.5} \text { : } \\
1.20(0.99-1.46) \text { and } \mathrm{NO}_{2} \text { : } \\
\text { OR: } 1.12(0.96-1.30) \text {. OR } \\
\text { of incident wheeze for } \\
\text { an IQR increase of } \mathrm{PM}_{2.5} \text { : } \\
1.14(1.04-1.26) \text {, and } \mathrm{NO}_{2} \text { : } \\
1.08(1.00-1.17)\end{array}$ & Smoking status & $\begin{array}{l}\text {-Smoking status: Never/ex- } \\
\text { smoker: } 1.14(1.04-1.24) \text {. } \\
\text { Current smoker: } 0.89(0.74- \\
1.06) \text { (p interaction=0.012) }\end{array}$ \\
\hline $\begin{array}{l}\text { Jacquemin, } \\
\text { 2015, EHP, [26] }\end{array}$ & $\begin{array}{l}6 \text { prospective } \\
\text { cohorts (ECRHS, } \\
\text { EGEA, SAPALDIA, } \\
\text { E3N, NHSD, } \\
\text { SALIA). }\end{array}$ & $\begin{array}{l}23704 \text { adults. } \\
\text { Mean age: } \\
\text { 60years }\end{array}$ & $\begin{array}{l}\text { ESCAPE project. } \mathrm{NO}_{2}, \mathrm{NOx} \text {, } \\
\mathrm{PM}_{10}, \mathrm{PM}_{2.5}, \mathrm{PM}_{2.5 a b s o r b a n c e} \\
\mathrm{Pm}_{\text {coarse }} \text { LUR model. Exposure } \\
\text { estimated at participant's } \\
\text { addresses. Back-extrapolated } \\
\text { concentrations of } \mathrm{NO}_{2} \text { and } \mathrm{PM}_{10} \\
\text { when necessary-according to } \\
\text { the year of the follow-up. Years } \\
\text { of exposure assessment: } 2010 \\
\text { or } 2011 \text {. }\end{array}$ & $\begin{array}{l}\text { Asthma incidence } \\
\text { positively, but NS, } \\
\text { associated with all } \\
\text { exposure metrics, except } \\
\text { for } \mathrm{PM}_{\text {coarse }} \text { OR: } \\
\mathrm{NO}_{2}: 1.10(0.99-1.21) \text { per } \\
10 \mathrm{mg} \cdot \mathrm{m}^{-3}, \mathrm{NOx} \text { : } \\
1.04(0.99-1.08 \text { per } \\
\text { 20mg. } \mathrm{m}^{-3}, \mathrm{PM}_{10} \text { : } \\
1.04(0.88-1.23) \text { per } \\
10 \mathrm{mg} \cdot \mathrm{m}^{-3}, \mathrm{PM}_{2.5} \text { : } \\
1.04(0.88-1.23) \text { per } \\
5 \mathrm{mg} \cdot \mathrm{m}^{-3}, \mathrm{PM} \mathrm{M}_{2.5 a b s o r b a n c e} \\
1.06(0.95-1.19) \text { per } 10- \\
5 / \mathrm{m} . \\
\text { Traffic load: } 1.10(0.93-\end{array}$ & $\begin{array}{l}\text { Sex, smoking } \\
\text { status, age }\end{array}$ & $\begin{array}{l}\text {-Sex: } \mathrm{NO}_{2} \text {. Men: } 1.06(0.92- \\
\text { 1.24). Women: } 1.07(0.97- \\
\text { 1.19) (p-interact=0.66). } \\
\mathrm{PM}_{10} \text { : Men:1.00(0.63-1.59) } \\
\text { Women:1.07(0.91-1.26) (p- } \\
\text { interact=0.80) } \\
\text {-Smoking status: } \\
\mathrm{NO}_{2}: \text { Ever-smokers: } \\
\text { 1.13(0.99-1.29). Never } \\
\text { smokers: } 1.01(0.88-1.16) \text {. } \\
\text { (P-interaction=0.35). } \\
\text { PM } 10 \text { : Ever- } \\
\text { smokers:1.17(0.79-1.74), } \\
\text { Never smokers:1.10(0.87- } \\
\text { 1.39), p-interact=0.69 } \\
\text {-Age By age: } \mathrm{NO}_{2}:\end{array}$ \\
\hline
\end{tabular}




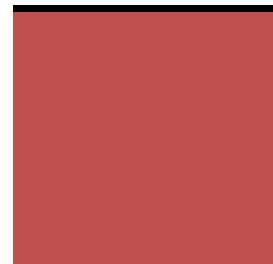

Traffic intensity:

1.10(0.93-1.30). $\mathrm{PM}_{\text {coarse }}$

0.98(0.87-1.14)

$<50: 1.08(0.96-1.21),>50$ :

1.02(0.94-1.12). (p-

interact $=0.88) . \mathrm{PM}_{10}:<50$ :

1.07(0.86-1.32) and $>50$ :

1.05(0.78-1.42) (p-

interact $=0.99$ ).

Abbreviations: OR: Odds Ratio, RR: Risk Ratio, HR: Hazard Ratio, Cl: Confidence Interval, PM: Particule Matter, $\mathrm{NO}_{2}$ : Nitrogen dioxyde, NOx: Nitrogen oxide,

$\mathrm{O}_{3}$ : ozone, IgE: Immunoglobulin E, SPT: Skin Prick Test, BHR: Bronchial Hyper Reactivity, NS: not significant, TRAP: Traffic Related Air Pollution 


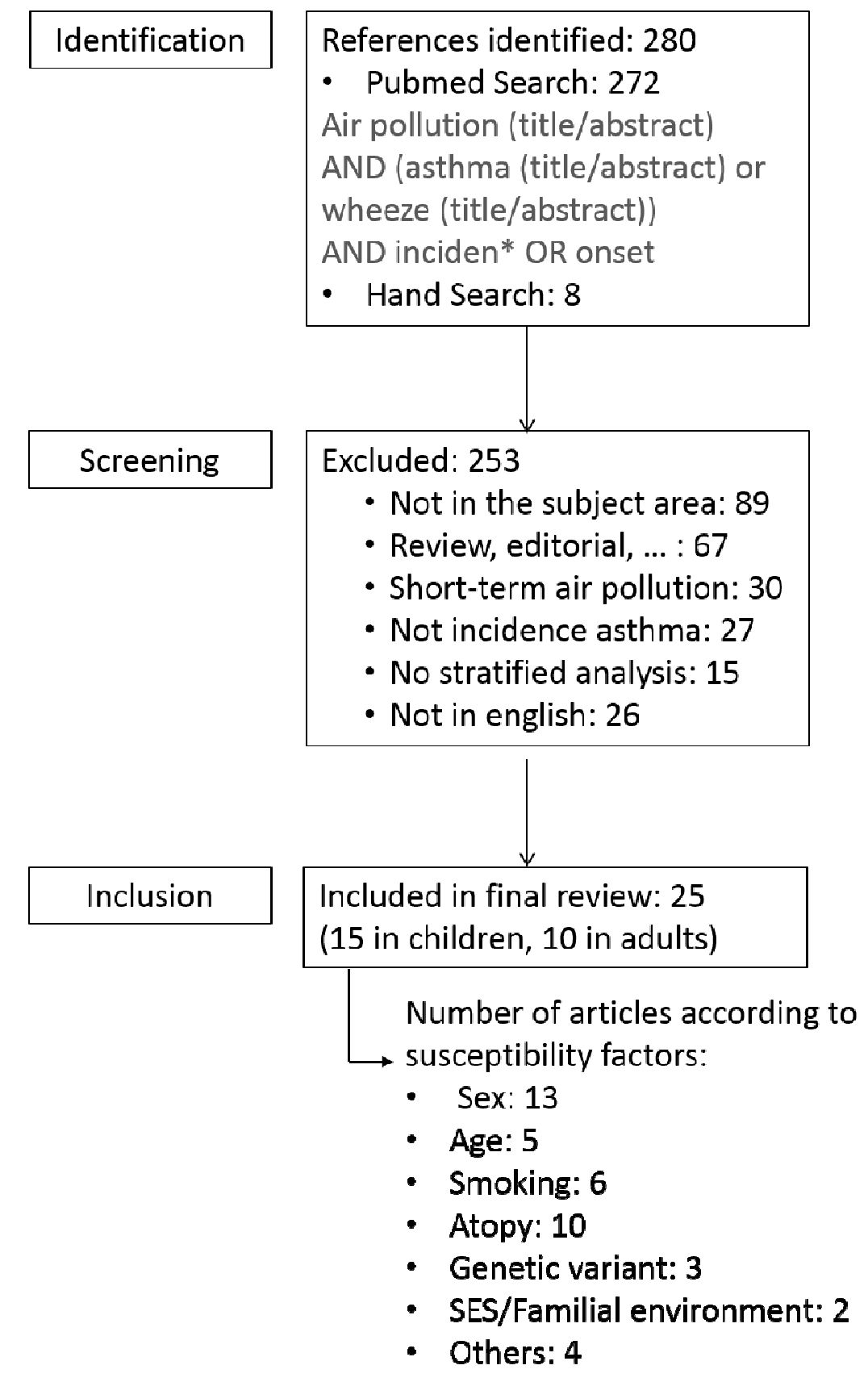

